Discussion Paper No. 06-079

\title{
Environmentally Oriented Energy Policy and Stock Returns: \\ An Empirical Analysis
}

Ulrich Oberndorfer and Andreas Ziegler

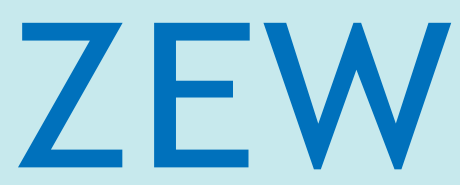

Zentrum für Europäische Wirtschaftsforschung $\mathrm{GmbH}$

Centre for European

Economic Research 
Discussion Paper No. 06-079

\title{
Environmentally Oriented Energy Policy and Stock Returns: An Empirical Analysis
}

\author{
Ulrich Oberndorfer and Andreas Ziegler
}

Download this ZEW Discussion Paper from our ftp server:

ftp://ftp.zew.de/pub/zew-docs/dp/dp06079.pdf

Die Discussion Papers dienen einer möglichst schnellen Verbreitung von neueren Forschungsarbeiten des ZEW. Die Beiträge liegen in alleiniger Verantwortung der Autoren und stellen nicht notwendigerweise die Meinung des ZEW dar.

Discussion Papers are intended to make results of ZEW research promptly available to other economists in order to encourage discussion and suggestions for revisions. The authors are solely responsible for the contents which do not necessarily represent the opinion of the ZEW. 


\section{Non-technical Summary}

This paper examines the effect of environmental regulation on stock returns (as a measure of economic performance) for German energy corporations. By using event study methodology (including insights from modern empirical finance and therefore also applying the FamaFrench three-factor model to estimate the abnormal daily and monthly stock returns), we consider the last minute victory of the acting government in the 2002 German federal elections to the Lower House of Parliament (Bundestag). Previous to the elections, the so-called "redgreen” government coalition consisting of Social Democrats and the Green party was considered to have about the same chance to win the majority in the Bundestag as the "blackyellow” opposition consisting of Christian Democrats and the Liberal party. Concerning German environmental and particularly energy policy, the result of the elections was crucial: While the "red-green" coalition was generally associated with a paradigm shift towards the promotion of renewable energies and a phasing out of nuclear energy, the "black-yellow" opposition signaled different priorities in line with traditional energy policy.

The main estimation results of the empirical analysis imply (1) no evidence of a general negative impact of the 2002 Bundestag elections on stock returns for traditional utilities and (2) a positive albeit transitory short-run effect for the entire group of renewable energy corporations. We conclude that the 2002 Bundestag elections and therefore stringent environmental regulation had at least no general negative effect on the economic performance of energy corporations. One reason for the insignificant abnormal stock returns could be that the environmentally oriented energy policy of the acting government was anticipated by the capital markets before the 2002 Bundestag elections even though the result of the elections was fully unpredictable. In this respect, it should be noted that Social Democrats and the Green party already formulated their environmental policy at the beginning of the legislation period in 1998 in the contract stating the political agenda of the coalition and in the following passed 
some corresponding laws. Therefore, it could be presumed that the traditional utilities reacted to comply with this environmental regulation by investing in new sustainable energies and technologies between 1998 and 2002. Another reason could be that the compliance costs of this energy policy were lower than expected or even negligible since the traditional utilities could excuse increases in electricity prices by the "green" policy of the government coalition. In this case, compliance costs could have been entirely borne by the final consumers of electricity also due to their low price elasticity of demand. 


\title{
Environmentally Oriented Energy Policy and Stock Returns: \\ An Empirical Analysis
}

\author{
Ulrich Oberndorfer ${ }^{1}$ and Andreas Ziegler ${ }^{2}$ *
}

November 2006

\begin{abstract}
This paper analyzes the effect of environmental regulation on stock returns (as a measure of economic performance) for German energy corporations. By using event study methodology, we consider the last minute victory of the acting government in the 2002 German federal elections to the Lower House of Parliament (Bundestag). The government coalition consisted of Social Democrats and the Green party and was generally associated with a paradigm shift in environmental and particularly energy policy towards the promotion of renewable energies and a phasing out of nuclear energy. In contrast, the opposing Christian Democrats and Liberal party signaled different priorities in line with traditional energy policy. Compared with other environmental event studies, we include insights from modern empirical finance and therefore also apply the Fama-French three-factor model to estimate the abnormal daily and monthly stock returns. The main estimation results of the empirical analysis imply (1) no evidence of a general negative impact of the 2002 Bundestag elections on stock returns for traditional utilities and (2) a positive albeit transitory short-run effect for the entire group of renewable energy corporations. We conclude that the 2002 Bundestag elections and therefore stringent environmental regulation had at least no general negative effect on the economic performance of energy corporations. One reason for this could be that the compliance costs of the government's environmentally oriented energy policy were lower for traditional utilities than expected.
\end{abstract}

Keywords: Environmental regulation, Energy policy, Nuclear energy, Renewable energies, Event study, CAPM, Market model, Three-factor model.

JEL classification: Q48, Q42, G14, G12.

\footnotetext{
${ }^{1}$ Centre for European Economic Research (ZEW), Department of Environmental and Resource Economics, Environmental Management, L 7,1, 68161 Mannheim, Germany, E-Mail: oberndorfer@zew.de, Phone: +49/621/ 1235-337.

${ }^{2}$ Centre for European Economic Research (ZEW), Department of Environmental and Resource Economics, Environmental Management, L 7,1, 68161 Mannheim, Germany, E-Mail: ziegler@zew.de, Phone: +49/621/ 1235-219, and Center for Corporate Responsibility and Sustainability (CCRS) at the University of Zurich, Künstlergasse 15a, 8001 Zurich, Switzerland, E-Mail: andreas.ziegler@ccrs.unizh.ch, Phone: +41/44/634-4020.

* Our special thanks go to Richard Stehle and Anja Schulz from Humboldt University Berlin, Germany, for providing the carefully controlled and edited financial data. We furthermore would like to thank Dorota Bayer, Ulf Moslener, Andreas Schrimpf, Michael Schröder, and Qingwei Wang for helpful comments and suggestions. Financial support from the Fritz Thyssen Stiftung is acknowledged.
} 


\section{Introduction}

The main goal of new and more stringent environmental regulation is in principle the protection of natural resources. However, the economic effect of environmental regulatory changes is also (particularly in periods of small economic growth) widely and controversially disputed (see, e.g., the discussion in Jaffe et al., 1994): On the one hand, it is argued that compliance with stringent national environmental regulation imposes significant costs for some polluting firms or sectors such that the profitability of these firms is hurt and therefore the competitiveness of the whole national economy can suffer. On the other hand, the popular Porter hypothesis suggests that environmental regulation provides incentives for companies to innovate and that these innovations can stimulate economic growth and competitiveness of the regulated country (Porter and van der Linde, 1995).

Indeed, the empirical micro-econometric analysis of the effect of environmental regulatory changes on the economic performance of firms or sectors is rather difficult. For example, if an environmental regulation affects an entire industry, the application of modern microevaluation techniques (e.g., Wooldridge, 2002) is problematic, particularly if yearly data are used. Generally, the impact of a regulation can hardly be separated from sectoral impacts if an analysis is based on yearly data as it is difficult to filter regulation effects from yearly variation. However, monthly or daily firm- or sector-level data are inappropriate for many indicators of competitiveness such as exports, sales, Tobin's Q, or return on assets in being too noisy to be a reliable indicator and are sometimes not even available for these intervals. Even applying panel data approaches the results can be misleading: For example, the use of pollution abatement expenditures as a comprehensive indicator for environmental regulatory burden (Pickman, 1998, Brunnermeier and Cohen, 2003) is problematic in providing a truly exogenous measure since the level of these costs also depends on the nature of an industry's response to environmental regulation (Jaffe and Palmer, 1997). 
In contrast, daily and monthly stock returns are easily accessible and seem furthermore reliable indicators for economic performance since the stock price fully reflects all available information on efficient capital markets (Fama, 1970) and therefore also reflects the discounted expected future cash flows for the investors. Based on this, event studies which aim to measure the effect of a specific event on the value of a corporation (MacKinley, 1997, Kothari and Warner, 2006) are a suitable tool to examine the impact of environmental regulation on the economic performance of affected corporations. However, this methodology can only be applied if an environmental regulation is actually an unexpected event. This is obviously the reason why event study methodology was seldom used in the past since most environmental regulatory changes are debated in the political arena over a long time such that wealth effects generally are gradually incorporated into the value of a corporation.

In this paper we examine the effect of the 2002 German federal elections to the Lower House of Parliament (Bundestag) on stock returns for German energy corporations by using this event study methodology. The acting government consisted of Social Democrats (SPD) and the Green party (Bündnis 90/Die Grünen) since the 1998 Bundestag elections. Previous to the 2002 Bundestag elections, this so-called “red-green” coalition was considered to have about the same chance to win the majority in the Bundestag as the "black-yellow" opposition consisting of Christian Democrats (CDU/CSU) and the Liberal party (FDP). The government coalition finally celebrated a last minute victory over their opponents, although at nearly the slightest possible margin (1.2 percent points of total votes, Gabriel and Völkl, 2003). Concerning German environmental and particularly energy policy, the result of the elections was crucial: While the "red-green" coalition was generally associated with a paradigm shift towards the promotion of renewable energies and a phasing out of nuclear energy, the "blackyellow” opposition signaled different priorities in line with traditional energy policy. According to this, we examine the hypotheses of negative abnormal stock returns for traditional utili- 
ties involved in nuclear energy and of positive abnormal stock returns for corporations exclusively engaged in renewable energies.

Methodologically, we include insights from modern empirical finance and therefore also apply the three-factor model of Fama and French (1993) to estimate the abnormal stock returns besides the one-factor model based on the CAPM (Capital Asset Pricing Model, Sharpe, 1964, Lintner, 1965) and the market model (Sharpe, 1963, Fama, 1968). In spite of the superiority of this three-factor model in the explanation of (portfolio) stock returns, environmental event studies commonly use the CAPM and particularly the market model so far. Furthermore, most previous studies exclusively analyze abnormal stock returns for several days around the considered event. However, it should be noted that daily data tend to be somewhat noisy such that asset pricing models based on this type of data do not work very well. Furthermore, a short-term overreaction of the stock markets is possible such that, for example, abnormal stock returns at the first day after the event can quickly vanish. Therefore, we apply both daily and monthly data in an additional longer-term analysis to examine whether possible very short-term abnormal returns persist over time.

The remainder of the paper is organized as follows: Section 2 presents the applied event study methodology and reviews environmental event studies. In section 3 a short overview of German environmentally oriented energy policy measures during the first legislation period of the “red-green” coalition between 1998 and 2002 is given. Section 4 describes the used data and some details of our event study. In section 5 the estimation results are presented and section 6 concludes. 


\section{Event Studies}

\subsection{Methodology}

Event studies try to examine the stock return behavior for corporations which experience a specific event and therefore aim to measure the effect on the value of a corporation (MacKinley, 1997, Kothari and Warner, 2006). The main features in the application of event studies have not been changed since their development by Ball and Brown (1968) and Fama et al. (1969). One important assumption in this respect is that capital markets are sufficiently efficient to react on events (i.e., new information) regarding expected future profits of affected corporations. Event studies are mostly rested upon the analysis of so-called "normal" and "abnormal" returns which are estimated on the basis of asset pricing models. The main approaches are the market model (Sharpe, 1963, Fama, 1968) and the one-factor model based on the CAPM (Sharpe, 1964, Lintner, 1965) and the market model. The market model for a corporation or stock $i$ at the end of period (day or month) $t(i=1, \ldots, N ; t=1, \ldots, T)$ is:

$$
r_{i t}=\alpha_{i}+\beta_{i} r_{m t}+\varepsilon_{i t}
$$

The combination of the market model and the CAPM leads to the following one-factor model:

$$
r_{i t}-r_{f t}=\alpha_{i}+\beta_{i}\left(r_{m t}-r_{f t}\right)+\varepsilon_{i t}
$$

In these models $r_{i t}$ and $r_{m t}$ are the returns for corporation $i$ and the market portfolio at the end of period $t$ (i.e., between $t-1$ and $t$ ), $r_{f t}$ is the risk-free interest rate at the beginning of period $t$, and $\varepsilon_{i t}$ is the disturbance term with $\mathrm{E}\left(\varepsilon_{i t}\right)=0$ and $\operatorname{var}\left(\varepsilon_{i t}\right)=\sigma_{\varepsilon}{ }^{2}$. Finally, $\alpha_{i}$ and $\beta_{i}$ besides $\sigma_{\varepsilon}{ }^{2}$ are the unknown parameters and have to be estimated (by OLS).

Against this background, the three-factor model of Fama and French (1993) includes the excess returns $r_{m t}-r_{f t}$ of the market portfolio and two additional factors to explain the excess returns $r_{i t}-r_{f t}$ : 


$$
r_{i t}-r_{f t}=\alpha_{i}+\beta_{i 1}\left(r_{m t}-r_{f t}\right)+\beta_{i 2} S M B_{t}+\beta_{i 3} H M L_{t}+\varepsilon_{i t}
$$

$S M B_{t}$ is the difference between the returns for a portfolio comprising stocks of "small” corporations and a portfolio comprising stocks of "big" corporations and $H M L_{t}$ is the difference between the returns for a portfolio comprising stocks of corporations with a "high" book-tomarket equity and a portfolio comprising stocks of corporations with a "low" book-to-market equity, respectively, in period $t$ (for details see Fama and French, 1993). The unknown parameters are now $\alpha_{i}, \beta_{i 1}, \beta_{i 2}$, and $\beta_{i 3}$ besides $\operatorname{var}\left(\varepsilon_{i t}\right)=\sigma_{\varepsilon}^{2}$. Many studies show that this threefactor model has more explanatory power than the one-factor model discussed above, for example, Fama and French (1993, 1996) for the U.S., Berkowitz and Qiu (2001) for the Canadian, Hussain et al. (2002) for the British, and Ziegler et al. (2007) for the German stock market. While such analyses are carried out with monthly data (and are performed for stock portfolios), we particularly examine daily data in this paper as it is common in event studies. It should be noted that we do not consider two additional bond market risk factors in a fivefactor model as suggested in Fama and French (1993) since they have no additional explanatory power for the German stock market (Ziegler et al., 2007).

Based on the one- or three-factor models, unknown normal (excess) returns $\mathrm{E}\left(r_{i t}-r_{f t}\right)$ are defined as the expected returns without conditioning on the event and abnormal returns ar $r_{i t}$ are defined as the actual minus the normal returns:

$$
\mathrm{a} r_{i t}=\left(r_{i t}-r_{f t}\right)-\mathrm{E}\left(r_{i t}-r_{f t}\right)
$$

The unknown parameters in $\mathrm{E}\left(r_{i t}-r_{f t}\right)$ are estimated on the basis of the one- or three-factor models for all $t$ in the time interval $\left[T_{0}, \ldots, T_{1}\right]$ which is called the estimation window. Based on this, the normal and abnormal returns are then estimated for each corporation $i$ and for separate periods $t$ in the time interval $\left[T_{1}+1, \ldots, T_{2}\right]$ which is called the event window. The estimated abnormal returns est $\left(\mathrm{a} r_{i}\right)$ in the one-factor model are then: 


$$
\operatorname{est}\left(\mathrm{a} r_{i t}\right)=\left(r_{i t}-r_{f t}\right)-\operatorname{est}\left(\alpha_{i}\right)-\operatorname{est}\left(\beta_{i}\right)\left(r_{m t}-r_{f t}\right)
$$

The corresponding estimated abnormal returns est $\left(\mathrm{a} r_{i}\right)$ in the Fama-French three-factor model are:

$$
\operatorname{est}\left(\mathrm{a} r_{i t}\right)=\left(r_{i t}-r_{f t}\right)-\operatorname{est}\left(\alpha_{i}\right)-\operatorname{est}\left(\beta_{i 1}\right)\left(r_{m t}-r_{f t}\right)-\operatorname{est}\left(\beta_{i 2}\right) S M B_{t}-\operatorname{est}\left(\beta_{i 3}\right) H M L_{t}
$$

If the estimation window is sufficiently large, the est $\left(\mathrm{a} r_{i}\right)$ are approximately normally distributed with $\mathrm{E}\left[\operatorname{est}\left(\mathrm{a} r_{i t}\right)\right]=0$ and $\operatorname{var}\left[\operatorname{est}\left(\mathrm{a} r_{i t}\right)\right]=\sigma_{\varepsilon}^{2}$ under the null hypothesis $H_{0}$ that the event has no impact.

The estimated abnormal returns can be aggregated across corporations and over time. For an aggregation across affected corporations the estimated average abnormal returns est( $\left(\mathrm{aa} r_{t}\right)$ for a period $t$ in the event window are the means of the estimated abnormal returns for the corporations $i=1, \ldots, N$ :

$$
\operatorname{est}\left(\mathrm{aa} r_{t}\right)=\frac{1}{N} \sum_{i=1}^{N} \operatorname{est}\left(\mathrm{a} r_{i t}\right)
$$

If the estimated abnormal returns are independent across corporations and if the estimation window is sufficiently large, the est(aa $\left.r_{t}\right)$ are approximately normally distributed with $\mathrm{E}\left[\operatorname{est}\left(\mathrm{aa} r_{t}\right)\right]=0$ and $\operatorname{var}\left[\operatorname{est}\left(\mathrm{aar}{ }_{t}\right)\right]=\sigma_{\varepsilon}^{2} 1 / N$ under the null hypothesis $H_{0}$ that the event has no impact.

For an aggregation over time the estimated cumulative abnormal returns est(car $r_{i}$ ) for a corporation $i$ are the sums of the considered estimated abnormal returns for all periods $t$ from $T_{\mathrm{a}}$ to $T_{\mathrm{b}}$ (with $T_{1}<T_{\mathrm{a}}<T_{\mathrm{b}}<T_{2}+1$ ):

$$
\operatorname{est}\left(\mathrm{ca} r_{i}\right)=\sum_{t=T_{\mathrm{a}}}^{T_{\mathrm{b}}} \operatorname{est}\left(\mathrm{a} r_{i t}\right)
$$


If the estimated abnormal returns are independent over time and if the estimation window is sufficiently large, the est $\left(\mathrm{car}_{i}\right)$ are approximately normally distributed with $\mathrm{E}\left[\operatorname{est}\left(\operatorname{car}_{i}\right)\right]=0$ and $\operatorname{var}\left[\operatorname{est}\left(\mathrm{car}_{i}\right)\right]=\sigma_{\varepsilon}{ }^{2}\left(T_{\mathrm{b}}-T_{\mathrm{a}}+1\right)$ under the null hypothesis $H_{0}$ that the event has no impact.

For a combined aggregation over time and across affected corporations the estimated average cumulative abnormal returns est(acar) are the means of the estimated cumulative abnormal returns for the corporations $i=1, \ldots, N$

$$
\operatorname{est}(\text { aca } r)=\frac{1}{N} \sum_{i=1}^{N} \operatorname{est}\left(\text { ca }_{i}\right)
$$

(or, alternatively, the sums of the estimated average abnormal returns over time from $T_{\mathrm{a}}$ to $T_{\mathrm{b}}$ ). If the estimated cumulative abnormal returns are independent across corporations and if the estimation window is sufficiently large, the est(acar) are approximately normally distributed with $\mathrm{E}[\operatorname{est}(\mathrm{aca} r)]=0$ and $\operatorname{var}[\operatorname{est}(\mathrm{aca} r)]=\sigma_{\varepsilon}{ }^{2}\left(T_{\mathrm{b}}-T_{\mathrm{a}}+1\right) 1 / N$ under the null hypothesis $H_{0}$ that the event has no impact.

In our event study we analyze individual and aggregate abnormal returns. Based on zstatistics which directly arise from the approximate normal distributions of est $\left(\mathrm{a} r_{i t}\right)$, est $\left(\mathrm{aar} r_{t}\right)$, est( $\left(\mathrm{ca}_{i}\right)$, and est(acar) under $H_{0}$, we can examine whether the 2002 Bundestag elections actually had an effect on stock returns. In this respect, we apply the traditional one-factor model based on the CAPM and the market model as well as the Fama-French three-factor model to check the robustness of the estimation results. We analyze several days after the elections as it is common in environmental event studies. According to Kothari and Warner (2006), daily data permit precise measurements of abnormal returns. Based on the assumption that capital markets are sufficiently efficient, these markets should react within a very short-term horizon (i.e., within the first day) after the elections since the new information is immediately available. However, it should be noted that daily data tend to be somewhat noisy such that corre- 
sponding asset pricing models do not work very well. Furthermore, a short-term overreaction of the stock markets is possible such that, for example, abnormal stock returns at the first day after the event can quickly vanish. Therefore, we apply both daily and monthly data in an additional longer-term analysis to examine whether possible very short-term abnormal returns persist over time. Due to data availability, the application of monthly data is only possible for traditional utilities involved in nuclear energy (see below).

\subsection{Environmental Event Studies}

Event studies are particularly applied in finance and accounting, for example, to examine the effect of mergers and acquisitions, earnings announcements, or issues of new debt or equity (MacKinley, 1997, Kothari and Warner, 2006). However, they are recently also increasingly used to analyze the impact of environmental news on economic performance. Many of these studies consider disclosures of information regarding positive or negative corporate environmental performance (Klassen and McLaughlin, 1996, Dasgupta et al., 2001, Gupta and Goldar, 2005, Capelle-Blancard and Laguna, 2006). Examples for positive news in this respect are investments in pollution control, environmental awards, or good environmental ratings by NGO. Examples for news regarding negative environmental performance are spills, environmental accidents, or bad environmental ratings by NGO. Another widespread indicator in such studies are disclosures of toxic releases (Hamilton, 1995, Konar and Cohen, 1997, Khanna et al., 1998).

These studies play an important role in the discussion of non-mandatory approaches in environmental policy to foster corporate environmental performance (Khanna, 2001). If the stock markets (as shown in many of those studies) react to bad environmental news with negative abnormal returns and to good environmental news with positive abnormal returns for the affected corporations, the release of information regarding corporate environmental perform- 
ance can be an important tool for environmental policy. These measures could in such cases supplement traditional mandatory environmental command and control regulation which is often considered to be too centralized instruments producing immense bureaucracy at the governmental level. Nevertheless, it should be noted that stringent environmental regulation cannot fully be substituted by these information oriented approaches to protect the natural resources, particularly if the stock markets do not react on corporate environmental news.

Similar conclusions can be drawn from event studies considering corporate environmental news which are more related to environmental regulation. These analyses consider the effect of violations of or non-compliance with environmental regulation or lawsuits due to such violations (Muoghalu et al., 1990, Laplante and Lanoie, 1994, Lanoie et al., 1998, Karpoff et al., 2005, Dasgupta et al., 2006). These studies can also contribute to a guideline for environmental policy. However, they do not examine the effect of environmental regulation itself on stock returns for affected corporations, either. One obvious reason for the rare application of event studies analyzing environmental regulation in the past is that this methodology requires that its announcement (or the announcement of regulation in general, Binder, 1985) constitutes an event that was not anticipated before. Indeed, most environmental regulation is debated in the political arena over a long time such that accompanying wealth effects generally are gradually incorporated into the value of a corporation.

One early event study analyzing the effect of environmental regulation can be found in Butler and McNertney (1991). This study even considers the effect of elections, namely the 1982 state-wide gubernatorial elections in six US states. These states were identified as those where the election results were uncertain and expected to affect environmental regulation for energy utilities. The study shows that in those states in which the victory of a Democratic governor was most unpredictable significantly negative cumulative abnormal returns arise. Blacconiere and Northcut (1997) consider the impact of the US Superfund Amendments and Reauthoriza- 
tion Act (SARA) of 1986 on stock returns for corporations from the chemical industry. While the study cannot find significant cumulative abnormal returns when all 26 SARA related events are considered, an analysis of only 17 of these events provides significantly negative cumulative abnormal returns. Tawil (1999) examines the 1994 US Supreme Court's ruling that flow-control laws are unconstitutional concerning abnormal returns for hauling-landfill or waste-to-energy corporations. However, no significant abnormal returns for any industry occur. Two recent studies consider the effect of the US Clean Air Act Amendments of 1990 on stock returns for energy utilities (Diltz, 2002, Kahn and Knittel, 2003). Both studies examine several milestones in the passage of the amendments. Kahn and Knittel (2003) also analyze the effect of the 1988 presidential elections. Obviously due to the long debate in the political arena, most of the analyzed events over the nearly two years produce no significant cumulative abnormal returns.

Methodologically, most environmental event studies consider the two-stage estimation as discussed above, i.e., in the first stage, the estimation of the asset pricing models’ parameters in the estimation window and based on this, in the second stage, the estimation of abnormal returns in the event window. Only some of them estimate the abnormal returns at once by including dummy variables in the OLS regression (Butler and McNertney, 1991, Blacconiere and Northcut, 1997, Kahn and Knittel, 2003). Furthermore, most studies (and in fact all studies cited above except Tawil, 1999, who use a multifactor model) apply versions of the market model or the one-factor model based on the CAPM and the market model with daily data. Diltz (2002) is one exemption in that he does not exclusively analyze abnormal returns for several days around the considered event but also considers monthly data therefore additionally examining a longer-term horizon.

However, a problem as aforementioned is that the market model (as the one-factor model) particularly on the basis of monthly data clearly works worse in explaining stock returns than 
the Fama-French three-factor model. As a consequence, the estimations of abnormal returns could be biased. To our knowledge, no environmental event study has applied the FamaFrench three-factor model so far as it is common in modern empirical finance. Even Tawil (1999) does not include the usual Fama-French risk factors in her multifactor model based on daily as well as weekly data. In contrast, we examine, on the one hand, both the one-factor model and the Fama-French three-factor model and, on the other hand, both daily and monthly (when traditional utilities involved in nuclear energy are considered) data to check the robustness of the estimation results regarding the effect of the 2002 Bundestag elections.

\section{German Environmentally Oriented Energy Policy from 1998 to 2002}

After the 1998 Bundestag elections the German Green party participated in a national government for the first time in history. The leading party of the corresponding "red-green” coalition were the Social Democrats. This coalition was generally associated with a paradigm shift in environmental and particularly energy policy as it was already formulated in the contract stating the political agenda of the coalition. According to this, German voters institutionalized a general policy that was also oriented on environmental targets (Oberndorfer, 2005). Two major goals for the legislation period of the "red-green" coalition towards an environmentally oriented energy policy were the promotion of renewable energies and a phasing out of nuclear energy. These goals formed already part of the officially announced program for the first 100 days of government (“100-Tage-Programm”).

Although the "red-green" coalition failed to implement this energy policy as quickly, it achieved at least a fundamental change until the end of the legislation period (Mez, 2003). In March 2000 the "Stromeinspeisungsgesetz", a law that served as an economic baseline for the supply of renewable energies since 1990, was replaced by a law institutionalizing the promotion of renewable energies (“Erneuerbare-Energien-Gesetz” or "EEG”). This law set technol- 
ogy specific feed-in tariffs above the prices for generating electricity from fossil fuels (e.g., coal or gas) while at the same time power distributors were obliged to buy this power. Stakeholders and environmental experts considered this law particularly successful due to the growing shares of "green energy" in overall energy generation in Germany and due to the high investments in the renewable energy sector (Kern et al., 2004). Furthermore, negotiations between the government and the power supply industry ("Energiekonsensgespräche") were conducted from the beginning of the legislation period. These negotiations led in June 2000 to an agreement (“Atomkonsens”) and in April 2002 to the amendment of a nuclear power law (“Atomgesetz”). According to this, the operation of existing nuclear power plants was restricted to an average regular duration of 32 years without financial compensation of the affected utilities and the future construction of new nuclear power plants was legally dispelled.

Against this background, Social Democrats and the Green party stood for their new environmentally oriented energy policy regarding the phasing out of nuclear energy and even suggested more pronounced measures towards the promotion of renewable energies (proposing a doubling of the share of renewable energies in overall power generation) in their campaigns for the 2002 Bundestag elections. In contrast, the opposing Christian Democrats and Liberal party signaled different priorities in line with traditional energy policy. They particularly proclaimed the comeback of nuclear energy. They questioned the danger of German nuclear power plants and furthermore argued that a phasing out of nuclear energy combined with excessive promotion of renewable energies could, on the one hand, increase electricity prices for households and industry and could, on the other hand, make it expensive to reach long-term climate policy goals. A withdrawal of the nuclear power law through the "black-yellow" opposition would have broadened the activity fields of traditional utilities.

Previous to the elections on September 22, 2002, the "red-green" coalition was considered to have about the same chance to win the majority in the Bundestag as the "black-yellow" oppo- 
sition. The government coalition finally celebrated a last minute victory over their opponents, although at nearly the slightest possible margin (1.2 percent points of total votes, Gabriel and Völkl, 2003). Due to the unpredictability of the elections result and the underlying different environmental and energy policy programs, we examine the hypotheses of negative abnormal stock returns for traditional utilities involved in nuclear energy and of positive abnormal stocks returns for corporations exclusively engaged in renewable energies.

\section{Data and Details of the Event Study}

In our event study we analyze the effect of the 2002 Bundestag elections on stock returns for German energy corporations. We consider as aforementioned two groups of energy corporations: Traditional utilities involved in nuclear energy and corporations exclusively engaged in renewable energies. Regarding the first group, financial data (stock returns, market and book values) for overall $N=5$ corporations are available, namely for ENBW, EON, MVV, RWE, and VATTENFALL. Regarding the second group, corresponding data for overall $N=7$ corporations are available, namely for EECH, ENERGIEKONTOR, NORDEX, SOLARPARC, SOLARWORLD, SUNWAYS, and UMWELTKONTOR.

Our financial data stem from a carefully controlled database for German stock corporations of Richard Stehle from Humboldt University Berlin, Germany (Stehle and Hartmond, 1991, Schulz and Stehle, 2002). The data contain the daily and monthly (discrete) stock returns $r_{i t}$ and $r_{m t}$ (in \%) for the aforementioned energy corporations and for the German market portfolio which comprises all stocks traded on the Frankfurt stock exchange. To calculate the two risk factors $S M B_{t}$ and $H M L_{t}$ for the estimation of the Fama-French three-factor model, the data also contain the market and book values of all corporations whose stocks are traded on the Frankfurt stock exchange except banks and insurances as well as stock corporations with negative book values (for details see Ziegler et al., 2007). The daily and monthly risk-free 
interest rates $r_{f t}$ (in \%) are based on the one-month Frankfurt Interbank Offered Rate (FIBOR) and the one-month Euro Interbank Offered Rate (EURIBOR).

Our analyzed event date is September 22, 2002, i.e., the date the Bundestag elections took place. When daily data are considered, we define the 120 trading days prior to this event as our estimation window $\left[T_{0}, \ldots, T_{1}\right]$. Therefore, $T_{0}=T_{1}-119$ represents April 5, 2002, and $T_{1}$ represents September 20, 2002. When monthly data are examined, we include all months from January 1993 in our estimation window. However, it should be noted that most renewable energy corporations are rather new such that the lengths $T_{1}-T_{0}+1$ of the estimation windows are typically very low in these cases. As a consequence, we do not consider this group of energy corporations in detail with monthly data. The estimation windows also start later than January 1993 for two out of the five traditional utilities involved in nuclear energy due to the lack of data with $T_{1}-T_{0}+1=58$ for ENBW, $T_{1}-T_{0}+1=41$ for MVV, and $T_{1}-T_{0}+1=116$ otherwise. Indeed, $T_{1}$ represents in all cases August 2002. These windows are used for the estimation of the unknown parameters $\alpha_{i}$ and $\beta_{i}$ in the one-factor model based on the CAPM and the market model as well as of the unknown parameters $\alpha_{i}, \beta_{i 1}, \beta_{i 2}$, and $\beta_{i 3}$ in the FamaFrench three-factor model.

Based on the parameter estimates est $\left(\alpha_{i}\right)$ and $\operatorname{est}\left(\beta_{i}\right)$ or $\operatorname{est}\left(\alpha_{i}\right)$, est $\left(\beta_{i 1}\right)$, est $\left(\beta_{i 2}\right)$, and est $\left(\beta_{i 3}\right)$, the abnormal returns are estimated (for the $i=1, \ldots, 5$ traditional utilities and the $i=1, \ldots, 7$ renewable energy corporations). When daily data are considered, we define as our event window $\left[T_{1}+1, \ldots, T_{2}\right]$ the 15 trading days after the 2002 Bundestag elections on September 22. Therefore, $T_{1}+1$ here is September 23, 2002, and $T_{2}$ represents October 11, 2002. In this event window all individual abnormal returns $\mathrm{a} r_{i}$ based on both the one-factor and three-factor models are estimated. In contrast, the average abnormal returns aa $r_{t}$ for the five traditional utilities and for the seven renewable energy corporations, respectively, are only estimated for $t$ $=T_{1}+1$. Furthermore, we estimate some cumulative abnormal returns ca $r_{i}$. While $T_{\mathrm{a}}$ is always 
$T_{1}+1$, we consider different time periods such that $T_{\mathrm{b}}$ varies between $T_{1}+2, T_{1}+5$, and $T_{1}+15$ and therefore the analyzed lengths of time periods vary between two, five, and 15 days. Finally, we estimate the average cumulative abnormal returns acar for the three aforementioned time periods.

When monthly data are considered for the five traditional utilities, we define as our event window $\left[T_{1}+1, \ldots, T_{2}\right]$ the three months after the 2002 Bundestag elections in September. Therefore, $T_{1}+1$ represents October 2002 and $T_{2}$ is December 2002. In this event window all individual abnormal returns $\mathrm{a} r_{i}$ are again estimated. In contrast, the average abnormal returns aar $r_{t}$ are only examined for $t=T_{1}+1$. Furthermore, we estimate the cumulative abnormal returns car $r_{i}$ with $T_{\mathrm{a}}=T_{1}+1$ and $T_{\mathrm{b}}=T_{1}+3$. Finally, the corresponding average cumulative abnormal returns acar are estimated. To compare the estimation results with monthly data, cumulative abnormal daily returns $\mathrm{ca}_{i}$ are also estimated for the periods from October 1 , 2002, to October 30, 2002, and from October 1, 2002, to December 30, 2002. In this respect, the event window as discussed above is (also for the seven renewable energy corporations) extended. Furthermore, the average cumulative abnormal daily returns acar are estimated for these two periods.

\section{Estimation Results}

\subsection{Traditional Utilities Involved in Nuclear Energy}

Table 1 reports for the five traditional utilities involved in nuclear energy summary statistics of the estimation results regarding abnormal returns for September 23, i.e., the day after the 2002 Bundestag elections, and some cumulative abnormal daily returns for different periods as well as estimated average abnormal returns for September 23 and some estimated average cumulative abnormal daily returns for different periods based on both the one- and the threefactor model, respectively. Table 2 (based on the one-factor model) and Table 3 (based on the 
three-factor model) additionally report for each of the five traditional utilities the corresponding estimated abnormal returns for each of the 15 trading days after the elections as well as corresponding estimated cumulative abnormal daily returns.

According to these tables, the average abnormal returns for September 23 and the average cumulative abnormal returns for the first two, five, and 15 days after the elections across all corporations do not differ from zero at any common level of significance, irrespective of the application of the one- or three-factor model. Instead, positive est $\left(\mathrm{a} r_{i}\right)$ arise for three out of the five traditional utilities for September 23 and positive est(car $\left.r_{i}\right)$ even arise for each of the traditional utilities from September 23 to September 27. However, a significant cumulative abnormal return for the first two, five, or 15 days after the elections occurs for none of the five traditional utilities. According to these estimation results, there is no evidence of a negative impact of the 2002 Bundestag elections on stock returns and therefore on the economic performance for the traditional utilities.

In contrast, the estimated average cumulative abnormal returns are negative for all trading days in October and for all trading days from October to December. Surprisingly, these average cumulative abnormal returns even differ from zero at the $10 \%$ level of significance for the latter period. As aforementioned, the robustness of these estimation results should be tested by the application of monthly data since asset pricing models based on daily data are less reliable than those based on monthly data. Table 4 reports summary statistics of the corresponding estimation results regarding abnormal returns for October, i.e., the month after the 2002 Bundestag elections, and cumulative abnormal monthly returns from October to December as well as estimated average abnormal returns for October and estimated average cumulative abnormal monthly returns from October to December. Table 5 additionally reports for each of the five traditional utilities the corresponding estimated abnormal returns for October, No- 
vember, and December, respectively, as well as the corresponding estimated cumulative abnormal monthly returns from October to December.

According to this, the tendency of the estimation results based on daily data is strengthened. The average abnormal returns for October are different from zero at the $10 \%$ level of significance and the average cumulative abnormal returns are different from zero at the $5 \%$ level of significance. However, it should be noted that these estimation results are exclusively triggered by strongly negative estimated abnormal monthly returns for only two utilities, namely EON and RWE. Therefore, we assume that these surprising negative estimated abnormal returns are influenced by other singular factors and not by the 2002 Bundestag elections since no significantly negative abnormal returns arise for the other three traditional utilities. Instead, even a significantly positive abnormal return for December occurs for ENBW and MVV. Furthermore, the stock markets should have reacted within a very short-term horizon if the elections actually had an impact since the new information was immediately available. As discussed above, however, no significant cumulative abnormal return in the first 15 days occurs for EON and RWE, either.

\subsection{Corporations Exclusively Engaged in Renewable Energies}

Table 6 reports for the seven corporations exclusively engaged in renewable energies (just like Table 1 for the five traditional utilities involved in nuclear energy) summary statistics of the estimation results regarding abnormal returns for September 23 and some cumulative abnormal daily returns for different periods as well as estimated average abnormal returns for September 23 and some estimated average cumulative abnormal daily returns for different periods. Additionally, Table 7 (based on the one-factor model) and Table 8 (based on the three-factor model) report (as Table 2 and Table 3 for the traditional utilities) for each of the seven renewable energy corporations the corresponding estimated abnormal returns for each 
of the 15 trading days after the elections as well as corresponding estimated cumulative abnormal daily returns.

According to these tables, positive est( $\left(\mathrm{a} r_{i}\right)$ for September 23 arise for six out of the seven renewable energy corporations and the average abnormal return for September 23 strongly differs from zero at the $1 \%$ level of significance. Furthermore, a significant cumulative abnormal return from September 23 to September 24 occurs. In this respect, the estimated impact of the 2002 Bundestag elections is stronger when the three-factor model is applied. However, a short-term overreaction of the stock markets is possible since the average cumulative abnormal returns for the first five and 15 days after the elections do not differ from zero at any common level of significance, irrespective of the application of the one- or three-factor model. Furthermore, it should be noted that the clearly positive est(aa $r_{t}$ ) for September 23 and the clearly positive est(acar) from September 23 to September 24 are strongly influenced by the est $\left(\mathrm{a} r_{i}\right)$ and est $\left(\mathrm{car}_{i}\right)$ for only one corporation, namely SUNWAYS.

Finally, the cumulative abnormal returns for all trading days in October and from October to December do not differ from zero at any common level of significance. Regarding the latter period, even clearly negative est( $\left(\mathrm{ca}_{i}\right)$ arise for six out of the seven renewable energy corporations, particularly for EECH. As a consequence, the est(acar) are also clearly negative. The similarity of these estimation results with those for the two traditional utilities EON and RWE strengthen our reasoning above that these negative estimated abnormal returns are influenced by other singular factors and not by the 2002 Bundestag elections. However, these estimation results for the seven renewable energy corporations should be treated with caution: On the one hand, the volatility of the corresponding daily stock returns is extremely high such that, for example, even an est(car $\left.r_{i}\right)$ of nearly $-50 \%$ for EECH from October 01 to December 30 does not lead to a rejection of the null hypothesis that the car $r_{i}$ is zero, irrespective of the application of the one- or three-factor model. On the other hand, it should be noted that the time 
series of daily returns show very often values of zero for renewable energy corporations (and to a clearly less extent for traditional utilities) since the corresponding stocks were not traded on these days.

\section{Conclusions}

This paper examines the effect of environmental regulation on stock returns and therefore on the economic performance for German energy corporations. It analyzes the last minute victory of the acting government consisting of Social Democrats and the Green party in the 2002 Bundestag elections. Previous to the elections, this "red-green" coalition was considered to have about the same chance to win the majority in the Bundestag as the "black-yellow" opposition consisting of Christian Democrats and the Liberal party. Concerning German environmental and particularly energy policy, the result of the elections was crucial: While the "redgreen" coalition was generally associated with a paradigm shift towards the promotion of renewable energies and a phasing out of nuclear energy, the "black-yellow" opposition signaled different priorities in line with traditional energy policy. The main estimation results of the event study imply (1) no evidence of a general negative impact of the 2002 Bundestag elections on stock returns for traditional utilities and (2) a positive albeit transitory short-run effect for the entire group of renewable energy corporations. We conclude that the 2002 Bundestag elections and therefore stringent environmental regulation had at least no general negative effect on the economic performance of energy corporations.

One reason for the insignificant abnormal stock returns could be that the environmentally oriented energy policy of the acting government was anticipated by the capital markets before the 2002 Bundestag elections even though the result of the elections was fully unpredictable. In this respect, it should be noted that Social Democrats and the Green party already formulated their environmental policy at the beginning of the legislation period in 1998 in the con- 
tract stating the political agenda of the coalition and in the following passed some corresponding laws. Therefore, it could be presumed that the traditional utilities reacted to comply with this environmental regulation by investing in new sustainable energies and technologies between 1998 and 2002. Another reason could be that the compliance costs of this energy policy were lower than expected or even negligible since the traditional utilities could excuse increases in electricity prices by the "green" policy of the government coalition. In this case, compliance costs could have been entirely borne by the final consumers of electricity also due to their low price elasticity of demand (Diltz, 2002, Kahn and Knittel, 2003).

Methodologically, the application of the Fama-French three-factor model leads in some cases to slightly different estimation results compared with the application of the one-factor model based on the CAPM and the market model. However, it should be noted that the use of both asset pricing models lead to basically the same conclusions of our event study. Nevertheless, we favor the application of modern asset pricing models in future environmental event studies to test the robustness of the estimation results as it is standard meanwhile in empirical finance. In this respect, an interesting direction for further research is the application of alternative multifactor models such as the four-factor model according to Carhart (1997).

Surprisingly, negative estimated cumulative abnormal returns for two traditional utilities involved in nuclear energy arise from October to December 2002. In this respect, the use of monthly data provides slightly different estimation results compared with the use of daily data. This supports our suggestion that asset pricing models based on monthly data should, if possible, be applied as a robustness check for the estimation results. In spite of these results, it should be noted that the stock markets should have reacted within a very short-term horizon if the 2002 Bundestag elections actually had an impact since the new information regarding environmentally oriented energy policy was immediately available. However, no significant 
cumulative abnormal return in the first 15 days after the elections occurs for any traditional utility.

Apart from this, it could be questioned whether our event study approach which was developed for short-term analyses is fully reliable for longer-term considerations. Therefore, another direction for further research is the application of long-term event study approaches as they were developed and applied in modern financial economics (e.g., Barber and Lyon, 1997, Kothari and Warner, 1997, Lyon et al., 1999, Mitchell und Stafford, 2000, Ho, 2005). A final direction for further research is the analysis of the robustness of our estimation results concerning the unreliable time series of daily stock returns (particularly regarding the examined renewable energy corporations). The fundamental question in this respect is whether repeated returns of zero (as a result of the fact that the corresponding stocks were not traded on these days) can lead to systematic biased estimates of abnormal returns. 


\section{References}

Ball, R. and P. Brown (1968), An Empirical Evaluation of Accounting Income Numbers, Journal of Accounting Research 6, 159-179.

Barber, B.M. and J.D. Lyon, (1997), Detecting Long-Run Abnormal Stock Returns: The Empirical Power and Specification of Test Statistics, Journal of Financial Economics 43, 341372.

Berkowitz, M.K. and J. Qiu (2001), Common Risk Factors in Explaining Canadian Equity Returns, University of Toronto.

Binder, J.J. (1985), Measuring the Effects of Regulation with Stock Price Data, Rand Journal of Economics 16, 167-183.

Blacconiere, W.G. and W.D. Northcut (1997), Environmental Information and Market Reactions to Environmental Legislation, Journal of Accounting, Auditing and Finance 12, 149178.

Brunnermeier, S.B. and M.A. Cohen (2003), Determinants of Environmental Innovation in US Manufacturing Industries, Journal of Environmental Economics and Management 45, 278-293.

Butler, M.R. and E.M. McNertney (1991), Election Returns as a Signal of Changing Regulatory Climate, Energy Economics 13, 48-54.

Capelle-Blancard, G. and M.-A. Laguna (2006), How Do Stock Markets React to Industrial Accidents? The Case of Chemical and Oil Industry, Paper presented at the $21^{\text {st }}$ Annual Congress of the European Economic Association, Vienna.

Carhart, M.M. (1997), On Persistence in Mutual Fund Performance, Journal of Finance, 5782. 
Dasgupta, S., B. Laplante, and M. Nlandu (2001), Pollution and Capital Markets in Developing Countries, Journal of Environmental Economics and Management 42, 310-335.

Dasgupta, S., J.H. Hong, B. Laplante, and N. Mamingi (2006), Disclosure of Environmental Violations and Stock Market in the Republic of Korea, Ecological Economics 58, 759-777.

Diltz, J.D. (2002), US Equity Markets and Environmental Policy: The Case of Electric Utility Investor Behaviour During the Passage of the Clean Air Act Amendments of 1990, Environmental and Resource Economics 23, 379-401.

Fama, E.F. (1968), Risk, Return, and Equilibrium: Some Clarifying Comments, Journal of Finance 23, 29-40.

Fama, E.F. (1970), Efficient Capital Markets: A Review of Theory and Empirical Work, Journal of Finance 25, 383-417.

Fama, E.F. and K.R. French (1993), Common Risk Factors in the Returns on Stocks and Bonds, Journal of Financial Economics 33, 3-56.

Fama, E.F. and K.R. French (1996), Multifactor Explanations of Asset Pricing Anomalies, Journal of Finance 51, 55-84.

Fama, E.F., L. Fisher, M. Jensen, and R. Roll (1969), The Adjustment of Stock Prices to New Information, International Economic Review 10, 1-21.

Hamilton, J.T. (1995), Pollution as News: Media and Stock Market Reactions to the Toxics Release Inventory Data, Journal of Environmental Economics and Management 28, 98-113.

Hussain, I., S. Toms, and S. Diacon (2002), Financial Distress, Single and Multifactor Tests and Comparisons of Asset Pricing Anomalies: New Evidence, Nottingham University Business School. 
Gabriel, O. and K. Völkl (2003), Die Bundestagswahl 2002: Erfolg in letzter Minute?, Wechselwirkungen - Jahrbuch aus Lehre und Forschung der Universität Stuttgart, 30-47.

Gupta, S. and B. Goldar (2005), Do Stock Markets Penalise Environment-Unfriendly Behaviour? Evidence from India, Ecological Economics 52, 81-95.

Ho, K.-Y. (2005), Long-horizon Abnormal Performance Following Rights Issues and Placings: Additional Evidence from the U.K. Market, Review of Financial Economics 14, 25-45.

Jaffe, A.B. and K. Palmer (1997), Environmental Regulation and Innovation: A Panel Data Study, Review of Economics and Statistics 79, 610-619.

Jaffe, A.B., S.R. Peterson, P.R. Portney, and R.N. Stavins (1994), Environmental Regulation and the Competitiveness of U.S. Manufacturing: What Does the Evidence Tell Us? Journal of Economic Literature 33, 132-163.

Kahn, S. and C.R. Knittel (2003), The Impact of the Clean Air Act Amendments of 1990 on Electric Utilities and Coal Mines: Evidence from the Stock Market, Working Paper, Department of Finance and Economics, Boston University.

Karpoff, J.M., J.R. Lott, and E.W. Wehrly (2005), The Reputational Penalties for Environmental Violations: Empirical Evidence, Journal of Law and Economics 48, 653-675.

Kern, K., S. Koenen, and T. Löffelsend (2004), Red-Green Environmental Policy in Germany: Strategies and Performance Patterns, in: Reutter, W. (ed.), Germany on the road to “Normalcy” - Policies and Politics of the Red-Green Federal Government (1998-2002), New York: Palgrave Macmillan, 183-208.

Khanna, M. (2001), Non-Mandatory Approaches to Environmental Protection, Journal of Economic Surveys 15, 291-324. 
Khanna, M., W.R. Quimo, and D. Bojilova (1998), Toxics Release Information: A Policy Tool for Environmental Protection, Journal of Environmental Economics and Management 36, 243-266.

Klassen, R.D. and C.P. McLaughlin (1996), The Impact of Environmental Management on Firm Performance, Management Science 42, 1199-1214.

Konar, S. and M.A. Cohen (2001), Does the Market Value Environmental Performance, Review of Economics and Statistics 83, 281-289.

Kothari, S.P. and J.B. Warner (1997), Measuring Long-Horizon Security Price Performance, Journal of Financial Economics 43, 301-339.

Kothari, S.P. and J.B. Warner (2006), Econometrics of Event Studies, in: B.E. Eckbo (ed.), Handbook of Corporate Finance: Empirical Corporate Finance, Elsevier / North-Holland.

Laplante, B. and P. Lanoie (1994), The Market Response to Environmental Incentives in Canada: A Theoretical and Empirical Analysis, Southern Economic Journal 60, 657-672.

Lanoie, P., B. Laplante, and M. Roy (1998), Can Capital Markets Create Incentives for Pollution Control? Ecological Economics 26, 31-41.

Lintner, J. (1965), The Valuation of Risk Assets and the Selection of Risky Investments in Stock Portfolios and Capital Budgets, Review of Economics and Statistics 47, 13-37.

Lyon, J.D., B.M. Barber, and C.-L. Tsai (1999), Improved Methods for Tests of Long-Run Abnormal Stock Returns, Journal of Finance 54, 165-201.

MacKinley, A.C. (1997), Event Studies in Economics and Finance, Journal of Economic Literature 35, 13-39. 
Mez, L. (2003), Ökologische Modernisierung und Vorreiterrolle in der Energie- und Umweltpolitik? Eine vorläufige Bilanz, in: Egle, C., T. Ostheim, and R. Zohlnhöfer (eds.), Das rot-grüne Projekt. Eine Bilanz der Regierung Schröder 1998-2002, Wiesbaden: Westdeutscher Verlag, 329-350.

Mitchell, M.L. and E. Stafford (2000), Managerial Decisions and Long-Term Stock Prize Performance, Journal of Business 73, 287-329.

Muoghalu, M.I., H.D. Robison, and J.L. Glascock (1990), Hazardous Waste Lawsuits, Stockholder Returns, and Deterrence, Southern Economic Journal 7, 357-370.

Oberndorfer, U. (2005), Erneuerbare Energien ohne energische Nachhaltigkeitspolitik, Ökologisches Wirtschaften 4/05, 10-11.

Pickman, H.A. (1998), The Effect of Environmental Regulation on Environmental Innovation, Business Strategy and the Environment 7, 223-233.

Porter, M. and C. van der Linde (1995), Green and Competitive: Ending the Stalemate, Harvard Business Review Sept.-Oct, 120-134.

Schulz, A. and R. Stehle (2002), Buchwert-Marktwert-Verhältnis, Size und Beta als Erklärungsvariable für die Renditen deutscher Aktien, Humboldt-Universität zu Berlin.

Sharpe, William F. (1963), A Simplified Model for Portfolio Analysis, Management Science 9, 277-293.

Sharpe, W.F. (1964), Capital Asset Prices: A Theory of Market Equilibrium under Conditions of Risk, Journal of Finance 19, 425-442.

Stehle, R. and A. Hartmond (1991), Durchschnittsrenditen deutscher Aktien 1954-1988, Kredit und Kapital 24, 371-411. 
Tawil, N. (1999), Flow Control and Rent Capture in Solid Waste Management, Journal of Environmental Economics and Management 37, 183-201.

Wooldridge, J.M. (2002), Econometric Analysis of Cross Section and Panel Data, Cambridge: MIT Press.

Ziegler, A., M. Schröder, A. Schulz, and R. Stehle (2007), Multifaktormodelle zur Erklärung deutscher Aktienrenditen: Eine empirische Analyse, Schmalenbachs Zeitschrift für betriebswirtschaftliche Forschung, forthcoming. 


\section{Appendix: Tables}

Table 1: Estimated abnormal returns est(a $\left.r_{i}\right)$, estimated average abnormal returns est(aa $\left.r_{t}\right)$, estimated cumulative abnormal returns est $\left(\mathrm{car}_{i}\right)$, and estimated average cumulative abnormal returns est(acar) for the five traditional utilities involved in nuclear energy, basis: daily data

\begin{tabular}{|c|c|c|c|c|}
\hline Day & $\begin{array}{l}\text { Number of } \\
\text { negative est(a } r_{i} \text { ) } \\
\text { based on the one- } \\
\text { factor model } \\
\text { (number of } \mathrm{a} r_{i} \\
\text { which differ from } \\
\text { zero at the } 5 \% \text { level } \\
\text { of significance) }\end{array}$ & $\begin{array}{l}\text { Number of } \\
\text { negative est(a } r_{i} \text { ) } \\
\text { based on the three- } \\
\text { factor model } \\
\text { (number of } \mathrm{a} r_{i} \\
\text { which differ from } \\
\text { zero at the } 5 \% \text { level } \\
\text { of significance) }\end{array}$ & $\begin{array}{l}\text { est(aar } r_{t} \text { ) based on } \\
\text { the one-factor } \\
\text { model } \\
\text { (z-statistic) }\end{array}$ & $\begin{array}{l}\text { est }\left(\mathrm{aa} r_{t}\right) \text { based on } \\
\text { the three-factor } \\
\text { model } \\
\text { (z-statistic) }\end{array}$ \\
\hline September 23 & $\begin{array}{c}2 \\
(0)\end{array}$ & $\begin{array}{c}2 \\
(0)\end{array}$ & $\begin{array}{c}0.11 \\
(0.18)\end{array}$ & $\begin{array}{c}0.29 \\
(0.46)\end{array}$ \\
\hline Period & $\begin{array}{l}\text { Number of } \\
\text { negative est( }\left(\mathrm{ca} r_{i}\right) \\
\text { based on the one- } \\
\text { factor model } \\
\text { (number of car } r_{i} \\
\text { which differ from } \\
\text { zero at the } 5 \% \text { level } \\
\text { of significance) }\end{array}$ & $\begin{array}{l}\text { Number of } \\
\text { negative est( }\left(\mathrm{ca} r_{i}\right) \\
\text { based on the three- } \\
\text { factor model } \\
\text { (number of } \mathrm{ca} r_{i} \\
\text { which differ from } \\
\text { zero at the } 5 \% \text { level } \\
\text { of significance) }\end{array}$ & $\begin{array}{l}\text { est(acar) based on } \\
\text { the one-factor } \\
\text { model } \\
\text { (z-statistics) }\end{array}$ & $\begin{array}{l}\text { est(acar) based on } \\
\text { the three-factor } \\
\text { model } \\
\text { (z-statistics) }\end{array}$ \\
\hline $\begin{array}{l}\text { September } 23- \\
\text { September } 24 \\
\text { (two trading days } \\
\text { after the event) }\end{array}$ & $\begin{array}{c}3 \\
(0)\end{array}$ & $\begin{array}{c}3 \\
(0)\end{array}$ & $\begin{array}{c}-0.97 \\
(-1.07)\end{array}$ & $\begin{array}{c}-0.67 \\
(-0.74)\end{array}$ \\
\hline $\begin{array}{l}\text { September } 23 \text { - } \\
\text { September } 27 \\
\text { (five trading days } \\
\text { after the event) }\end{array}$ & $\begin{array}{c}0 \\
(0)\end{array}$ & $\begin{array}{c}0 \\
(0)\end{array}$ & $\begin{array}{c}1.42 \\
(0.99)\end{array}$ & $\begin{array}{c}1.74 \\
(1.22)\end{array}$ \\
\hline $\begin{array}{l}\text { September } 23- \\
\text { October } 11 \\
\text { ( } 15 \text { trading days } \\
\text { after the event) }\end{array}$ & $\begin{array}{c}3 \\
(0)\end{array}$ & $\begin{array}{c}2 \\
(0)\end{array}$ & $\begin{array}{c}-0.81 \\
(-0.33)\end{array}$ & $\begin{array}{c}-0.07 \\
(-0.03)\end{array}$ \\
\hline $\begin{array}{l}\text { October } 01 \text { - } \\
\text { October } 31\end{array}$ & $\begin{array}{c}5 \\
(0)\end{array}$ & $\begin{array}{c}5 \\
(0)\end{array}$ & $\begin{array}{c}-4.29 \\
(-1.43)\end{array}$ & $\begin{array}{c}-4.12 \\
(-1.38)\end{array}$ \\
\hline $\begin{array}{l}\text { October } 01 \text { - } \\
\text { December } 30\end{array}$ & $\begin{array}{c}3 \\
(1)\end{array}$ & $\begin{array}{c}3 \\
(1)\end{array}$ & $\begin{array}{c}-8.65^{*} \\
(-1.72)\end{array}$ & $\begin{array}{c}-8.90^{*} \\
(-1.78)\end{array}$ \\
\hline
\end{tabular}

Note: $*(*, * *)$ means that the null hypothesis that the average abnormal returns aa $r_{t}$ or the average cumulative abnormal returns acar are zero can be rejected at the $10 \%(5 \%, 1 \%)$ level of significance (according to the corresponding two-tailed z-test). 
Table 2: Estimated abnormal returns est $\left(\mathrm{a} r_{i}\right)$ and estimated cumulative abnormal returns est $\left(\mathrm{ca}_{i}\right)$ for each of the five traditional utilities involved in nuclear energy, basis: daily data and one-factor model

\begin{tabular}{|c|c|c|c|c|c|}
\hline & ENBW & EON & MVV & RWE & VATTENFALL \\
\hline Day & \multicolumn{5}{|c|}{$\begin{array}{l}\left.\text { Estimated abnormal returns est(a } r_{i}\right) \\
\text { (z-statistics) }\end{array}$} \\
\hline September 23 & $\begin{array}{c}0.22 \\
(0.28)\end{array}$ & $\begin{array}{c}-1.14 \\
(-0.76)\end{array}$ & $\begin{array}{c}1.80 \\
(1.25)\end{array}$ & $\begin{array}{l}-0.48 \\
(-0.32)\end{array}$ & $\begin{array}{c}0.17 \\
(0.10)\end{array}$ \\
\hline September 24 & $\begin{array}{c}0.18 \\
(0.22)\end{array}$ & $\begin{array}{l}-1.16 \\
(-0.77)\end{array}$ & $\begin{array}{c}-0.51 \\
(-0.36)\end{array}$ & $\begin{array}{l}-2.07 \\
(-1.38)\end{array}$ & $\begin{array}{l}-1.84 \\
(-1.07)\end{array}$ \\
\hline September 25 & $\begin{array}{c}1.36^{*} \\
(1.70)\end{array}$ & $\begin{array}{c}2.41 \\
(1.60)\end{array}$ & $\begin{array}{c}0.34 \\
(0.24)\end{array}$ & $\begin{array}{c}1.56 \\
(1.04)\end{array}$ & $\begin{array}{c}1.07 \\
(0.62)\end{array}$ \\
\hline September 26 & $\begin{array}{l}-1.68^{* *} \\
(-2.10) \\
\end{array}$ & $\begin{array}{l}6.62^{* * *} \\
(4.40) \\
\end{array}$ & $\begin{array}{c}-0.92 \\
(-0.63)\end{array}$ & $\begin{array}{l}5.39^{* * * *} \\
(3.61) \\
\end{array}$ & $\begin{array}{c}-1.54 \\
(-0.89)\end{array}$ \\
\hline September 27 & $\begin{array}{c}0.19 \\
(0.24) \\
\end{array}$ & $\begin{array}{c}-2.29 \\
(-1.52)\end{array}$ & $\begin{array}{c}0.95 \\
(0.66)\end{array}$ & $\begin{array}{l}-4.04^{* * *} \\
(-2.71)\end{array}$ & $\begin{array}{c}2.49 \\
(1.44) \\
\end{array}$ \\
\hline September 30 & $\begin{array}{c}0.31 \\
(0.38)\end{array}$ & $\begin{array}{l}3.90^{* * * *} \\
(2.59)\end{array}$ & $\begin{array}{c}0.49 \\
(0.34) \\
\end{array}$ & $\begin{array}{c}2.15 \\
(1.44) \\
\end{array}$ & $\begin{array}{c}0.19 \\
(0.11)\end{array}$ \\
\hline October 01 & $\begin{array}{c}-0.17 \\
(-0.21) \\
\end{array}$ & $\begin{array}{r}2.76^{*} \\
(1.83) \\
\end{array}$ & $\begin{array}{c}-1.35 \\
(-0.93)\end{array}$ & $\begin{array}{c}-0.61 \\
(-0.41) \\
\end{array}$ & $\begin{array}{c}-0.77 \\
(-0.45) \\
\end{array}$ \\
\hline October 02 & $\begin{array}{c}-0.11 \\
(-0.14)\end{array}$ & $\begin{array}{r}2.93^{*} \\
(1.95)\end{array}$ & $\begin{array}{l}-1.26 \\
(-0.87)\end{array}$ & $\begin{array}{l}5.17^{* * * *} \\
(3.46)\end{array}$ & $\begin{array}{c}-0.22 \\
(-0.13)\end{array}$ \\
\hline October 03 & $\begin{array}{c}0.23 \\
(0.28)\end{array}$ & $\begin{array}{c}0.04 \\
(0.02)\end{array}$ & $\begin{array}{c}0.01 \\
(0.00)\end{array}$ & $\begin{array}{c}-1.18 \\
(-0.79)\end{array}$ & $\begin{array}{c}2.72 \\
(1.57)\end{array}$ \\
\hline October 04 & $\begin{array}{c}0.20 \\
(0.25) \\
\end{array}$ & $\begin{array}{c}-2.85^{*} \\
(-1.90) \\
\end{array}$ & $\begin{array}{c}1.32 \\
(0.92) \\
\end{array}$ & $\begin{array}{c}-1.53 \\
(-1.02) \\
\end{array}$ & $\begin{array}{c}-0.43 \\
(-0.25) \\
\end{array}$ \\
\hline October 07 & $\begin{array}{c}0.12 \\
(0.14) \\
\end{array}$ & $\begin{array}{c}0.00 \\
(0.00) \\
\end{array}$ & $\begin{array}{c}0.83 \\
(0.57) \\
\end{array}$ & $\begin{array}{c}0.61 \\
(0.40) \\
\end{array}$ & $\begin{array}{l}-2.06 \\
(-1.19) \\
\end{array}$ \\
\hline October 08 & $\begin{array}{c}0.11 \\
(0.14)\end{array}$ & $\begin{array}{c}2.42 \\
(1.61)\end{array}$ & $\begin{array}{c}0.48 \\
(0.33)\end{array}$ & $\begin{array}{l}3.70^{* * *} \\
(2.47)\end{array}$ & $\begin{array}{l}-1.06 \\
(-0.61)\end{array}$ \\
\hline October 09 & $\begin{array}{c}0.07 \\
(0.09)\end{array}$ & $\begin{array}{l}-5.78^{* * *} \\
(-3.84)\end{array}$ & $\begin{array}{l}-2.93^{* * *} \\
(-2.03)\end{array}$ & $\begin{array}{l}-3.23^{* *} \\
(-2.16)\end{array}$ & $\begin{array}{c}0.52 \\
(0.30)\end{array}$ \\
\hline October 10 & $\begin{array}{c}-0.27 \\
(-0.34)\end{array}$ & $\begin{array}{l}-4.66^{* * *} \\
(-3.10)\end{array}$ & $\begin{array}{c}0.86 \\
(0.60) \\
\end{array}$ & $\begin{array}{l}-3.58^{* *} \\
(-2.40) \\
\end{array}$ & $\begin{array}{c}-0.37 \\
(-0.21) \\
\end{array}$ \\
\hline October 11 & $\begin{array}{c}-0.41 \\
(-0.51)\end{array}$ & $\begin{array}{l}-2.60^{*} \\
(-1.73)\end{array}$ & $\begin{array}{c}-1.44 \\
(-1.00)\end{array}$ & $\begin{array}{l}-3.88^{* * *} \\
(-2.59)\end{array}$ & $\begin{array}{c}-0.51 \\
(-0.29)\end{array}$ \\
\hline Period & \multicolumn{5}{|c|}{$\begin{array}{l}\left.\text { Estimated cumulative abnormal returns est(car } r_{i}\right) \\
\text { (z-statistics) }\end{array}$} \\
\hline $\begin{array}{l}\text { September } 23- \\
\text { September } 24\end{array}$ & $\begin{array}{c}0.40 \\
(0.35)\end{array}$ & $\begin{array}{l}-2.30 \\
(-1.08)\end{array}$ & $\begin{array}{c}1.28 \\
(0.63)\end{array}$ & $\begin{array}{l}-2.54 \\
(-1.20)\end{array}$ & $\begin{array}{l}-1.67 \\
(-0.68)\end{array}$ \\
\hline $\begin{array}{l}\text { September } 23- \\
\text { September } 27\end{array}$ & $\begin{array}{c}0.27 \\
(0.15)\end{array}$ & $\begin{array}{c}4.43 \\
(1.32)\end{array}$ & $\begin{array}{c}1.66 \\
(0.51)\end{array}$ & $\begin{array}{c}0.37 \\
(0.11)\end{array}$ & $\begin{array}{c}0.35 \\
(0.09)\end{array}$ \\
\hline $\begin{array}{l}\text { September } 23 \text { - } \\
\text { October } 11\end{array}$ & $\begin{array}{c}0.34 \\
(0.11)\end{array}$ & $\begin{array}{c}0.57 \\
(0.10)\end{array}$ & $\begin{array}{c}-1.33 \\
(-0.24)\end{array}$ & $\begin{array}{c}-2.02 \\
(-0.35)\end{array}$ & $\begin{array}{l}-1.63 \\
(-0.24)\end{array}$ \\
\hline $\begin{array}{l}\text { October } 01- \\
\text { October } 31\end{array}$ & $\begin{array}{c}-0.53 \\
(-0.14) \\
\end{array}$ & $\begin{array}{c}-9.94 \\
(-1.41)\end{array}$ & $\begin{array}{c}-5.24 \\
(-0.77)\end{array}$ & $\begin{array}{c}-1.16 \\
(-0.17)\end{array}$ & $\begin{array}{c}-4.55 \\
(-0.56) \\
\end{array}$ \\
\hline $\begin{array}{l}\text { October } 01 \text { - } \\
\text { December } 30\end{array}$ & $\begin{array}{c}8.27 \\
(1.31)\end{array}$ & $\begin{array}{l}-25.57^{* *} \\
(-2.16)\end{array}$ & $\begin{array}{c}1.67 \\
(0.15)\end{array}$ & $\begin{array}{l}-21.98^{*} \\
(-1.87)\end{array}$ & $\begin{array}{c}-5.62 \\
(-0.41)\end{array}$ \\
\hline
\end{tabular}

Note: $*(* *, * *)$ means that the null hypothesis that the abnormal returns $\mathrm{a} r_{\mathrm{i}}$ or the cumulative abnormal returns $\mathrm{car}_{i}$ are zero can be rejected at the $10 \%$ (5\%, 1\%) level of significance (according to the corresponding twotailed z-test). 
Table 3: Estimated abnormal returns est $\left(\mathrm{a} r_{i}\right)$ and estimated cumulative abnormal returns est $\left(\mathrm{ca}_{i}\right)$ for each of the five traditional utilities involved in nuclear energy, basis: daily data and three-factor model

\begin{tabular}{|c|c|c|c|c|c|}
\hline & ENBW & EON & MVV & RWE & VATTENFALL \\
\hline Day & \multicolumn{5}{|c|}{$\begin{array}{l}\left.\text { Estimated abnormal returns est(a } r_{i}\right) \\
\text { (z-statistics) }\end{array}$} \\
\hline September 23 & $\begin{array}{c}0.30 \\
(0.37)\end{array}$ & $\begin{array}{l}-1.08 \\
(-0.72)\end{array}$ & $\begin{array}{c}1.98 \\
(1.38)\end{array}$ & $\begin{array}{c}-0.23 \\
(-0.15)\end{array}$ & $\begin{array}{c}0.50 \\
(0.29)\end{array}$ \\
\hline September 24 & $\begin{array}{c}0.26 \\
(0.33)\end{array}$ & $\begin{array}{l}-1.16 \\
(-0.77)\end{array}$ & $\begin{array}{c}-0.34 \\
(-0.24)\end{array}$ & $\begin{array}{l}-1.95 \\
(-1.31)\end{array}$ & $\begin{array}{l}-1.61 \\
(-0.94)\end{array}$ \\
\hline September 25 & $\begin{array}{r}1.32^{*} \\
(1.66)\end{array}$ & $\begin{array}{c}2.38 \\
(1.59)\end{array}$ & $\begin{array}{c}0.25 \\
(0.17)\end{array}$ & $\begin{array}{c}1.45 \\
(0.98)\end{array}$ & $\begin{array}{c}0.92 \\
(0.54)\end{array}$ \\
\hline September 26 & $\begin{array}{c}-1.50^{*} \\
(-1.89) \\
\end{array}$ & $\begin{array}{l}6.50^{* * * *} \\
(4.33) \\
\end{array}$ & $\begin{array}{c}-0.59 \\
(-0.41)\end{array}$ & $\begin{array}{l}5.29^{* * * *} \\
(3.55) \\
\end{array}$ & $\begin{array}{c}-1.36 \\
(-0.79) \\
\end{array}$ \\
\hline September 27 & $\begin{array}{c}0.27 \\
(0.33) \\
\end{array}$ & $\begin{array}{c}-2.36 \\
(-1.58) \\
\end{array}$ & $\begin{array}{c}1.09 \\
(0.76)\end{array}$ & $\begin{array}{l}-4.14^{* * *} \\
(-2.79)\end{array}$ & $\begin{array}{c}2.52 \\
(1.47) \\
\end{array}$ \\
\hline September 30 & $\begin{array}{c}0.18 \\
(0.23)\end{array}$ & $\begin{array}{l}4.10^{* * * *} \\
(2.73) \\
\end{array}$ & $\begin{array}{c}0.29 \\
(0.20) \\
\end{array}$ & $\begin{array}{r}2.53^{*} \\
(1.70) \\
\end{array}$ & $\begin{array}{c}0.32 \\
(0.18)\end{array}$ \\
\hline October 01 & $\begin{array}{c}-0.06 \\
(-0.07) \\
\end{array}$ & $\begin{array}{r}2.62^{*} \\
(1.75) \\
\end{array}$ & $\begin{array}{c}-1.16 \\
(-0.81)\end{array}$ & $\begin{array}{c}-0.83 \\
(-0.56) \\
\end{array}$ & $\begin{array}{c}-0.78 \\
(-0.46) \\
\end{array}$ \\
\hline October 02 & $\begin{array}{c}0.03 \\
(0.04) \\
\end{array}$ & $\begin{array}{c}2.91^{*} \\
(1.94)\end{array}$ & $\begin{array}{c}-0.96 \\
(-0.67)\end{array}$ & $\begin{array}{l}5.31^{* * *} \\
(3.57)\end{array}$ & $\begin{array}{c}0.12 \\
(0.07) \\
\end{array}$ \\
\hline October 03 & $\begin{array}{c}0.27 \\
(0.34)\end{array}$ & $\begin{array}{c}-0.02 \\
(-0.01)\end{array}$ & $\begin{array}{c}0.08 \\
(0.06)\end{array}$ & $\begin{array}{c}-1.27 \\
(-0.85)\end{array}$ & $\begin{array}{c}2.70 \\
(1.57)\end{array}$ \\
\hline October 04 & $\begin{array}{c}0.15 \\
(0.19) \\
\end{array}$ & $\begin{array}{c}-2.76^{*} \\
(-1.84) \\
\end{array}$ & $\begin{array}{c}1.26 \\
(0.87) \\
\end{array}$ & $\begin{array}{c}-1.34 \\
(-0.90) \\
\end{array}$ & $\begin{array}{c}-0.34 \\
(-0.20)\end{array}$ \\
\hline October 07 & $\begin{array}{c}0.28 \\
(0.36) \\
\end{array}$ & $\begin{array}{c}-0.14 \\
(-0.09) \\
\end{array}$ & $\begin{array}{c}1.14 \\
(0.79)\end{array}$ & $\begin{array}{c}0.45 \\
(0.30) \\
\end{array}$ & $\begin{array}{c}-1.93 \\
(-1.12) \\
\end{array}$ \\
\hline October 08 & $\begin{array}{c}0.01 \\
(0.01)\end{array}$ & $\begin{array}{c}2.50^{*} \\
(1.67)\end{array}$ & $\begin{array}{c}0.29 \\
(0.20)\end{array}$ & $\begin{array}{l}3.81^{* *} \\
(2.56)\end{array}$ & $\begin{array}{l}-1.12 \\
(-0.65)\end{array}$ \\
\hline October 09 & $\begin{array}{c}0.16 \\
(0.20)\end{array}$ & $\begin{array}{l}-5.81^{* * *} \\
(-3.87)\end{array}$ & $\begin{array}{l}-2.76^{*} \\
(-1.92)\end{array}$ & $\begin{array}{l}-3.21^{* *} \\
(-2.16)\end{array}$ & $\begin{array}{c}0.68 \\
(0.39)\end{array}$ \\
\hline October 10 & $\begin{array}{c}-0.12 \\
(-0.15) \\
\end{array}$ & $\begin{array}{l}-4.78^{* * *} \\
(-3.18) \\
\end{array}$ & $\begin{array}{c}1.14 \\
(0.79) \\
\end{array}$ & $\begin{array}{l}-3.71^{* *} \\
(-2.50) \\
\end{array}$ & $\begin{array}{c}-0.25 \\
(-0.14) \\
\end{array}$ \\
\hline October 11 & $\begin{array}{c}-0.40 \\
(-0.51)\end{array}$ & $\begin{array}{c}-2.64^{*} \\
(-1.76)\end{array}$ & $\begin{array}{c}-1.45 \\
(-1.01)\end{array}$ & $\begin{array}{l}-3.97^{* * * *} \\
(-2.67)\end{array}$ & $\begin{array}{c}-0.58 \\
(-0.34)\end{array}$ \\
\hline Period & \multicolumn{5}{|c|}{$\begin{array}{l}\left.\text { Estimated cumulative abnormal returns est(car } r_{i}\right) \\
\text { (z-statistics) }\end{array}$} \\
\hline $\begin{array}{l}\text { September } 23- \\
\text { September } 24\end{array}$ & $\begin{array}{c}0.56 \\
(0.49)\end{array}$ & $\begin{array}{c}-2.24 \\
(-1.05)\end{array}$ & $\begin{array}{c}1.64 \\
(0.81)\end{array}$ & $\begin{array}{l}-2.17 \\
(-1.03)\end{array}$ & $\begin{array}{l}-1.11 \\
(-0.46)\end{array}$ \\
\hline $\begin{array}{l}\text { September } 23- \\
\text { September } 27\end{array}$ & $\begin{array}{c}0.64 \\
(0.36)\end{array}$ & $\begin{array}{c}4.28 \\
(1.28)\end{array}$ & $\begin{array}{c}2.39 \\
(0.74)\end{array}$ & $\begin{array}{c}0.42 \\
(0.13)\end{array}$ & $\begin{array}{c}0.97 \\
(0.25)\end{array}$ \\
\hline $\begin{array}{l}\text { September } 23 \text { - } \\
\text { October } 11\end{array}$ & $\begin{array}{c}1.14 \\
(0.37)\end{array}$ & $\begin{array}{c}0.27 \\
(0.05)\end{array}$ & $\begin{array}{c}0.27 \\
(0.05)\end{array}$ & $\begin{array}{c}-1.81 \\
(-0.31)\end{array}$ & $\begin{array}{c}-0.21 \\
(-0.03)\end{array}$ \\
\hline $\begin{array}{l}\text { October } 01- \\
\text { October } 31\end{array}$ & $\begin{array}{c}-0.18 \\
(-0.05)\end{array}$ & $\begin{array}{l}-10.20 \\
(-1.45) \\
\end{array}$ & $\begin{array}{c}-4.59 \\
(-0.68)\end{array}$ & $\begin{array}{c}-1.42 \\
(-0.20)\end{array}$ & $\begin{array}{c}-4.22 \\
(-0.52)\end{array}$ \\
\hline $\begin{array}{l}\text { October } 01 \text { - } \\
\text { December } 30\end{array}$ & $\begin{array}{c}8.21 \\
(1.31)\end{array}$ & $\begin{array}{c}-25.70^{* *} \\
(-2.17)\end{array}$ & $\begin{array}{c}1.50 \\
(0.13)\end{array}$ & $\begin{array}{l}-22.42^{*} \\
(-1.91)\end{array}$ & $\begin{array}{c}-6.08 \\
(-0.45)\end{array}$ \\
\hline
\end{tabular}

Note: $*(* *, * * *)$ means that the null hypothesis that the abnormal returns a $r_{\mathrm{i}}$ or the cumulative abnormal returns $\mathrm{car}_{i}$ are zero can be rejected at the $10 \%$ (5\%, 1\%) level of significance (according to the corresponding twotailed z-test). 
Table 4: Estimated abnormal returns est(a $\left.r_{i}\right)$, estimated average abnormal returns est(aa $\left.r_{t}\right)$, estimated cumulative abnormal returns est $\left(\mathrm{car}_{i}\right)$, and estimated average cumulative abnormal returns est(acar) for the five traditional utilities involved in nuclear energy, basis: monthly data

\begin{tabular}{|c|c|c|c|c|}
\hline Month & $\begin{array}{l}\text { Number of } \\
\text { negative est(a } r_{i} \text { ) } \\
\text { based on the one- } \\
\text { factor model } \\
\text { (number of } \mathrm{a} r_{i} \\
\text { which differ from } \\
\text { zero at the } 5 \% \text { level } \\
\text { of significance) }\end{array}$ & $\begin{array}{l}\text { Number of } \\
\text { negative est( }\left(\mathrm{a} r_{i}\right) \\
\text { based on the three- } \\
\text { factor model } \\
\text { (number of } \mathrm{a} r_{i} \\
\text { which differ from } \\
\text { zero at the } 5 \% \text { level } \\
\text { of significance) }\end{array}$ & $\begin{array}{l}\text { est( }\left(\mathrm{aa} r_{t}\right) \text { based on } \\
\text { the one-factor } \\
\text { model } \\
\text { (z-statistic) }\end{array}$ & $\begin{array}{l}\text { est }\left(\mathrm{aa} r_{t}\right) \text { based on } \\
\text { the three-factor } \\
\text { model } \\
\text { (z-statistic) }\end{array}$ \\
\hline October & $\begin{array}{c}5 \\
(0)\end{array}$ & $\begin{array}{c}5 \\
(0)\end{array}$ & $\begin{array}{c}-4.50^{*} \\
(-1.72)\end{array}$ & $\begin{array}{c}-4.69^{*} \\
(-1.85)\end{array}$ \\
\hline Period & $\begin{array}{l}\text { Number of } \\
\text { negative est(car } r_{i} \text { ) } \\
\text { based on the one- } \\
\text { factor model } \\
\text { (number of car } r_{i} \\
\text { which differ from } \\
\text { zero at the } 5 \% \text { level } \\
\text { of significance) }\end{array}$ & $\begin{array}{l}\text { Number of } \\
\text { negative est }\left(\mathrm{car}_{i}\right) \\
\text { based on the three- } \\
\text { factor model } \\
\text { (number of car } r_{i} \\
\text { which differ from } \\
\text { zero at the } 5 \% \text { level } \\
\text { of significance) }\end{array}$ & $\begin{array}{l}\text { est(acar) based on } \\
\text { the one-factor } \\
\text { model } \\
\text { (z-statistic) }\end{array}$ & $\begin{array}{l}\text { est(acar) based } \\
\text { on the three- } \\
\text { factor model } \\
\text { (z-statistic) }\end{array}$ \\
\hline $\begin{array}{l}\text { October - } \\
\text { December }\end{array}$ & $\begin{array}{c}3 \\
(2)\end{array}$ & $\begin{array}{c}4 \\
(2)\end{array}$ & $\begin{array}{c}-9.60^{* *} \\
(-2.12)\end{array}$ & $\begin{array}{l}-10.87^{* *} \\
(-2.47)\end{array}$ \\
\hline
\end{tabular}

Note: $\left.{ }^{* * *}, * * *\right)$ means that the null hypothesis that the average abnormal returns aa $r_{t}$ or the average cumulative abnormal returns acar are zero can be rejected at the $10 \%(5 \%, 1 \%)$ level of significance (according to the corresponding two-tailed z-test). 
Table 5: Estimated abnormal returns est $\left(\mathrm{a} r_{i}\right)$ and estimated cumulative abnormal returns est(car $\left.r_{i}\right)$ for each of the five traditional utilities involved in nuclear energy, basis: daily data and three-factor model

\begin{tabular}{|c|c|c|c|c|c|}
\hline \multicolumn{6}{|c|}{ Basis: One-factor model } \\
\hline & ENBW & EON & MVV & RWE & VATTENFALL \\
\hline Month & \multicolumn{5}{|c|}{$\begin{array}{l}\left.\text { Estimated abnormal returns est(a } r_{i}\right) \\
\text { (z-statistics) }\end{array}$} \\
\hline October & $\begin{array}{c}-2.04 \\
(-0.41)\end{array}$ & $\begin{array}{l}-12.41^{*} \\
(-1.80)\end{array}$ & $\begin{array}{c}-4.15 \\
(-0.71) \\
\end{array}$ & $\begin{array}{c}-0.06 \\
(-0.01) \\
\end{array}$ & $\begin{array}{l}-3.85 \\
(-0.73)\end{array}$ \\
\hline November & $\begin{array}{c}-5.83 \\
(-1.15)\end{array}$ & $\begin{array}{c}-8.47 \\
(-1.23)\end{array}$ & $\begin{array}{c}-7.17 \\
(-1.23)\end{array}$ & $\begin{array}{l}-15.63^{* * *} \\
(-2.59)\end{array}$ & $\begin{array}{c}2.29 \\
(0.43)\end{array}$ \\
\hline December & $\begin{array}{l}14.20^{* * *} \\
(2.82)\end{array}$ & $\begin{array}{c}-5.74 \\
(-0.83) \\
\end{array}$ & $\begin{array}{l}11.46^{* *} \\
(1.97) \\
\end{array}$ & $\begin{array}{l}-7.19 \\
(-1.19) \\
\end{array}$ & $\begin{array}{c}-3.40 \\
(-0.64) \\
\end{array}$ \\
\hline Period & \multicolumn{5}{|c|}{$\begin{array}{l}\text { Estimated cumulative abnormal returns est( }\left(\mathrm{ca}_{i}\right) \\
\text { (z-statistics) }\end{array}$} \\
\hline $\begin{array}{l}\text { October - } \\
\text { December }\end{array}$ & $\begin{array}{c}6.34 \\
(0.73)\end{array}$ & $\begin{array}{l}-26.62^{* * *} \\
(-2.90)\end{array}$ & $\begin{array}{c}0.15 \\
(0.01)\end{array}$ & $\begin{array}{l}-22.89^{* *} \\
(-2.27)\end{array}$ & $\begin{array}{l}-4.96 \\
(-0.42)\end{array}$ \\
\hline \multicolumn{6}{|c|}{ Basis: Three-factor model } \\
\hline & ENBW & EON & MVV & RWE & VATTENFALL \\
\hline Month & \multicolumn{5}{|c|}{$\begin{array}{l}\text { Estimated abnormal returns est }\left(\mathrm{a} r_{i}\right) \\
\text { (z-statistics) }\end{array}$} \\
\hline October & $\begin{array}{c}-0.66 \\
(-0.13)\end{array}$ & $\begin{array}{l}-12.84^{*} \\
(-1.88)\end{array}$ & $\begin{array}{l}-4.12 \\
(-0.75)\end{array}$ & $\begin{array}{c}-2.15 \\
(-0.37)\end{array}$ & $\begin{array}{l}-3.67 \\
(-0.72)\end{array}$ \\
\hline November & $\begin{array}{c}-5.54 \\
(-1.11) \\
\end{array}$ & $\begin{array}{c}-9.65 \\
(-1.42) \\
\end{array}$ & $\begin{array}{c}-8.94 \\
(-1.63) \\
\end{array}$ & $\begin{array}{l}-16.62^{* * *} \\
(-2.86)\end{array}$ & $\begin{array}{c}1.51 \\
(0.30) \\
\end{array}$ \\
\hline December & $\begin{array}{l}14.35^{* * *} \\
(2.88)\end{array}$ & $\begin{array}{c}-6.33 \\
(-0.93) \\
\end{array}$ & $\begin{array}{l}11.91^{* *} \\
(2.17)\end{array}$ & $\begin{array}{l}-7.88 \\
(-1.36) \\
\end{array}$ & $\begin{array}{l}-3.74 \\
(-0.74) \\
\end{array}$ \\
\hline Period & \multicolumn{5}{|c|}{$\begin{array}{l}\left.\text { Estimated cumulative abnormal returns est(car } r_{i}\right) \\
\text { (z-statistics) }\end{array}$} \\
\hline $\begin{array}{l}\text { October - } \\
\text { December }\end{array}$ & $\begin{array}{l}8.15 \\
(0.94)\end{array}$ & $\begin{array}{l}-28.81^{* * *} \\
(-3.28)\end{array}$ & $\begin{array}{l}-1.15 \\
(-0.11)\end{array}$ & $\begin{array}{l}-26.65^{* * *} \\
(-2.80)\end{array}$ & $\begin{array}{l}-5.89 \\
(-0.50)\end{array}$ \\
\hline
\end{tabular}

Note: * (**,***) means that the null hypothesis that the abnormal returns a $r_{\mathrm{i}}$ or the cumulative abnormal returns $\mathrm{car}_{i}$ are zero can be rejected at the $10 \%$ (5\%, 1\%) level of significance (according to the corresponding twotailed z-test). 
Table 6: Estimated abnormal returns est(a $\left.r_{i}\right)$, estimated average abnormal returns est(aa $\left.r_{t}\right)$, estimated cumulative abnormal returns est $\left(\mathrm{car}_{i}\right)$, and estimated average cumulative abnormal returns est(acar) for the seven corporations exclusively engaged in renewable energies, basis: daily data

\begin{tabular}{|c|c|c|c|c|}
\hline Day & $\begin{array}{l}\text { Number of } \\
\text { positive est }\left(\mathrm{a} r_{i}\right) \\
\text { based on the one- } \\
\text { factor model } \\
\text { (number of } a_{i} \\
\text { which differ from } \\
\text { zero at the } 5 \% \text { level } \\
\text { of significance) }\end{array}$ & $\begin{array}{l}\text { Number of } \\
\text { positive est( }\left(\mathrm{a} r_{i}\right) \\
\text { based on the three- } \\
\text { factor model } \\
\text { (number of } \mathrm{a}_{i} \\
\text { which differ from } \\
\text { zero at the } 5 \% \text { level } \\
\text { of significance) }\end{array}$ & $\begin{array}{l}\text { est }\left(\text { aa } r_{t} \text { ) based on }\right. \\
\text { the one-factor } \\
\text { model } \\
\text { (z-statistic) }\end{array}$ & $\begin{array}{l}\text { est }\left(\text { aa } r_{t} \text { ) based on }\right. \\
\text { the three-factor } \\
\text { model } \\
\text { (z-statistic) }\end{array}$ \\
\hline September 23 & $\begin{array}{c}6 \\
(1)\end{array}$ & $\begin{array}{c}6 \\
(1)\end{array}$ & $\begin{array}{l}5.22^{* * *} \\
(2.89)\end{array}$ & $\begin{array}{l}5.72^{* * *} \\
(3.18)\end{array}$ \\
\hline Period & $\begin{array}{l}\text { Number of } \\
\text { positive est(car } r_{i} \text { ) } \\
\text { based on the one- } \\
\text { factor model } \\
\text { (number of car } r_{i} \\
\text { which differ from } \\
\text { zero at the } 5 \% \text { level } \\
\text { of significance) }\end{array}$ & $\begin{array}{l}\text { Number of } \\
\text { positive est(car } r_{i} \text { ) } \\
\text { based on the three- } \\
\text { factor model } \\
\text { (number of } \mathrm{car}_{i} \\
\text { which differ from } \\
\text { zero at the } 5 \% \text { level } \\
\text { of significance) }\end{array}$ & $\begin{array}{l}\text { est(acar) based on } \\
\text { the one-factor } \\
\text { model } \\
\text { (z-statistics) }\end{array}$ & $\begin{array}{l}\text { est(acar) based on } \\
\text { the three-factor } \\
\text { model } \\
\text { (z-statistics) }\end{array}$ \\
\hline $\begin{array}{l}\text { September } 23 \text { - } \\
\text { September } 24 \\
\text { (two trading days } \\
\text { after the event) }\end{array}$ & $\begin{array}{c}6 \\
(0)\end{array}$ & $\begin{array}{c}6 \\
(1)\end{array}$ & $\begin{array}{r}4.69^{*} \\
(1.83)\end{array}$ & $\begin{array}{c}5.58^{* *} \\
(2.19)\end{array}$ \\
\hline $\begin{array}{l}\text { September } 23 \text { - } \\
\text { September } 27 \\
\text { (five trading days } \\
\text { after the event) }\end{array}$ & $\begin{array}{c}4 \\
(0)\end{array}$ & $\begin{array}{c}4 \\
(0)\end{array}$ & $\begin{array}{c}1.41 \\
(0.35)\end{array}$ & $\begin{array}{c}2.66 \\
(0.66)\end{array}$ \\
\hline $\begin{array}{l}\text { September } 23 \text { - } \\
\text { October } 11 \\
\text { (15 trading days } \\
\text { after the event) }\end{array}$ & $\begin{array}{c}2 \\
(0)\end{array}$ & $\begin{array}{c}2 \\
(0)\end{array}$ & $\begin{array}{c}-6.71 \\
(-0.96)\end{array}$ & $\begin{array}{c}-3.93 \\
(-0.56)\end{array}$ \\
\hline $\begin{array}{l}\text { October } 01 \text { - } \\
\text { October } 31\end{array}$ & $\begin{array}{c}5 \\
(0)\end{array}$ & $\begin{array}{c}6 \\
(0)\end{array}$ & $\begin{array}{c}5.83 \\
(0.69)\end{array}$ & $\begin{array}{c}6.64 \\
(0.79)\end{array}$ \\
\hline $\begin{array}{l}\text { October } 01 \text { - } \\
\text { December } 30\end{array}$ & $\begin{array}{c}1 \\
(0)\end{array}$ & $\begin{array}{c}1 \\
(0)\end{array}$ & $\begin{array}{l}-17.05 \\
(-1.20)\end{array}$ & $\begin{array}{l}-17.97 \\
(-1.27)\end{array}$ \\
\hline
\end{tabular}

Note: * $(* *, * * *)$ means that the null hypothesis that the average abnormal returns aar $r_{t}$ or the average cumulative abnormal returns acar are zero can be rejected at the 10\% (5\%, 1\%) level of significance (according to the corresponding two-tailed z-test). 
Table 7: Estimated abnormal returns est $\left(\mathrm{a} r_{i}\right)$ and estimated cumulative abnormal returns est $\left(\mathrm{car}_{i}\right)$ for each of the seven corporations exclusively engaged in renewable energies, basis: daily data and one-factor model

\begin{tabular}{|c|c|c|c|c|c|c|c|}
\hline & EECH & $\begin{array}{l}\text { ENERGIE- } \\
\text { KONTOR }\end{array}$ & NORDEX & $\begin{array}{l}\text { SOLAR- } \\
\text { PARC }\end{array}$ & $\begin{array}{l}\text { SOLAR- } \\
\text { WORLD }\end{array}$ & $\begin{array}{l}\text { SUN- } \\
\text { WAYS }\end{array}$ & $\begin{array}{l}\text { UMWELT- } \\
\text { KONTOR }\end{array}$ \\
\hline Day & \multicolumn{7}{|c|}{$\begin{array}{l}\text { Estimated abnormal returns est }\left(\mathrm{a} r_{i}\right) \\
\text { (z-statistics) }\end{array}$} \\
\hline September 23 & $\begin{array}{c}-4.52 \\
(-0.85)\end{array}$ & $\begin{array}{c}8.15^{*} \\
(1.78)\end{array}$ & $\begin{array}{c}3.15 \\
(0.80)\end{array}$ & $\begin{array}{c}0.79 \\
(0.19)\end{array}$ & $\begin{array}{c}7.21 \\
(1.55)\end{array}$ & $\begin{array}{l}13.08^{* *} \\
(2.42)\end{array}$ & $\begin{array}{r}8.72^{*} \\
(1.66)\end{array}$ \\
\hline September 24 & $\begin{array}{r}9.49^{*} \\
(1.77) \\
\end{array}$ & $\begin{array}{l}-7.06 \\
(-1.55)\end{array}$ & $\begin{array}{l}-5.07 \\
(-1.29)\end{array}$ & $\begin{array}{c}4.19 \\
(1.02)\end{array}$ & $\begin{array}{c}-6.11 \\
(-1.32)\end{array}$ & $\begin{array}{c}1.82 \\
(0.34)\end{array}$ & $\begin{array}{l}-1.00 \\
(-0.19)\end{array}$ \\
\hline September 25 & $\begin{array}{l}-11.07^{* *} \\
(-2.07)\end{array}$ & $\begin{array}{c}4.07 \\
(0.89)\end{array}$ & $\begin{array}{c}-4.46 \\
(-1.13)\end{array}$ & $\begin{array}{c}0.35 \\
(0.09)\end{array}$ & $\begin{array}{l}-3.36 \\
(-0.72)\end{array}$ & $\begin{array}{l}-2.59 \\
(-0.48)\end{array}$ & $\begin{array}{c}2.07 \\
(0.39)\end{array}$ \\
\hline September 26 & $\begin{array}{c}2.58 \\
(0.48)\end{array}$ & $\begin{array}{l}-7.83^{*} \\
(-1.71)\end{array}$ & $\begin{array}{c}0.14 \\
(0.04)\end{array}$ & $\begin{array}{c}0.40 \\
(0.10)\end{array}$ & $\begin{array}{c}0.22 \\
(0.05)\end{array}$ & $\begin{array}{l}-1.55 \\
(-0.29)\end{array}$ & $\begin{array}{l}-2.57 \\
(-0.49)\end{array}$ \\
\hline September 27 & $\begin{array}{l}-9.77^{*} \\
(-1.82) \\
\end{array}$ & $\begin{array}{l}-9.13^{* *} \\
(-2.00)\end{array}$ & $\begin{array}{c}0.71 \\
(0.18)\end{array}$ & $\begin{array}{c}0.70 \\
(0.17)\end{array}$ & $\begin{array}{l}9.09^{* *} \\
(1.96)\end{array}$ & $\begin{array}{c}2.34 \\
(0.43) \\
\end{array}$ & $\begin{array}{c}6.73 \\
(1.28) \\
\end{array}$ \\
\hline September 30 & $\begin{array}{c}-1.94 \\
(-0.36)\end{array}$ & $\begin{array}{c}7.28 \\
(1.59)\end{array}$ & $\begin{array}{c}-0.30 \\
(-0.08)\end{array}$ & $\begin{array}{c}0.81 \\
(0.20)\end{array}$ & $\begin{array}{c}-10.75^{* *} \\
(-2.32)\end{array}$ & $\begin{array}{c}-9.19^{*} \\
(-1.70)\end{array}$ & $\begin{array}{c}2.87 \\
(0.55)\end{array}$ \\
\hline October 01 & $\begin{array}{l}-34.53^{*+*} \\
(-6.45)\end{array}$ & $\begin{array}{l}-3.47 \\
(-0.76)\end{array}$ & $\begin{array}{c}-11.77^{* * * *} \\
(-2.99)\end{array}$ & $\begin{array}{c}0.34 \\
(0.08)\end{array}$ & $\begin{array}{c}-1.92 \\
(-0.41)\end{array}$ & $\begin{array}{c}-2.27 \\
(-0.42)\end{array}$ & $\begin{array}{c}-12.72^{* *} \\
(-2.42)\end{array}$ \\
\hline October 02 & $\begin{array}{l}-17.78^{* * *} \\
(-3.32)\end{array}$ & $\begin{array}{c}-0.92 \\
(-0.20)\end{array}$ & $\begin{array}{c}2.94 \\
(0.75)\end{array}$ & $\begin{array}{c}0.40 \\
(0.10)\end{array}$ & $\begin{array}{c}-2.34 \\
(-0.50)\end{array}$ & $\begin{array}{c}-9.03^{*} \\
(-1.67)\end{array}$ & $\begin{array}{c}-5.68 \\
(-1.08)\end{array}$ \\
\hline October 03 & $\begin{array}{c}2.82 \\
(0.53)\end{array}$ & $\begin{array}{c}8.46^{*} \\
(1.85)\end{array}$ & $\begin{array}{c}-0.33 \\
(-0.08)\end{array}$ & $\begin{array}{c}2.46 \\
(0.60)\end{array}$ & $\begin{array}{c}1.24 \\
(0.27)\end{array}$ & $\begin{array}{c}2.82 \\
(0.52)\end{array}$ & $\begin{array}{c}6.13 \\
(1.17)\end{array}$ \\
\hline October 04 & $\begin{array}{l}31.72^{* * * *} \\
(5.93)\end{array}$ & $\begin{array}{c}-1.78 \\
(-0.39)\end{array}$ & $\begin{array}{c}1.64 \\
(0.42) \\
\end{array}$ & $\begin{array}{c}0.71 \\
(0.17) \\
\end{array}$ & $\begin{array}{c}4.61 \\
(0.99)\end{array}$ & $\begin{array}{c}-8.35 \\
(-1.55)\end{array}$ & $\begin{array}{c}1.33 \\
(0.25)\end{array}$ \\
\hline October 07 & $\begin{array}{c}6.29 \\
(1.18)\end{array}$ & $\begin{array}{c}7.27 \\
(1.59)\end{array}$ & $\begin{array}{c}2.55 \\
(0.65)\end{array}$ & $\begin{array}{c}-1.07 \\
(-0.26)\end{array}$ & $\begin{array}{c}-6.65 \\
(-1.43)\end{array}$ & $\begin{array}{c}4.42 \\
(0.82)\end{array}$ & $\begin{array}{c}0.03 \\
(0.01)\end{array}$ \\
\hline October 08 & $\begin{array}{c}-4.23 \\
(-0.79) \\
\end{array}$ & $\begin{array}{c}-0.68 \\
(-0.15)\end{array}$ & $\begin{array}{c}2.15 \\
(0.55)\end{array}$ & $\begin{array}{c}0.62 \\
(0.15) \\
\end{array}$ & $\begin{array}{c}7.85^{*} \\
(1.69) \\
\end{array}$ & $\begin{array}{c}-4.58 \\
(-0.85)\end{array}$ & $\begin{array}{c}-9.71^{*} \\
(-1.85) \\
\end{array}$ \\
\hline October 09 & $\begin{array}{l}-14.64^{*+4 *} \\
(-2.73)\end{array}$ & $\begin{array}{c}-2.99 \\
(-0.65)\end{array}$ & $\begin{array}{c}4.02 \\
(1.02)\end{array}$ & $\begin{array}{c}0.58 \\
(0.14)\end{array}$ & $\begin{array}{c}-1.78 \\
(-0.38)\end{array}$ & $\begin{array}{c}0.84 \\
(0.16)\end{array}$ & $\begin{array}{c}-4.49 \\
(-0.86)\end{array}$ \\
\hline October 10 & $\begin{array}{c}7.10 \\
(1.33)\end{array}$ & $\begin{array}{c}-4.40 \\
(-0.96)\end{array}$ & $\begin{array}{l}-11.69 \\
(-2.97)\end{array}$ & $\begin{array}{c}0.25 \\
(0.06)\end{array}$ & $\begin{array}{c}-6.41 \\
(-1.38)\end{array}$ & $\begin{array}{c}5.86 \\
(1.08)\end{array}$ & $\begin{array}{c}0.97 \\
(0.18)\end{array}$ \\
\hline October 11 & $\begin{array}{c}4.59 \\
(0.86) \\
\end{array}$ & $\begin{array}{c}-4.55 \\
(-0.99) \\
\end{array}$ & $\begin{array}{c}6.23 \\
(1.58) \\
\end{array}$ & $\begin{array}{c}7.01^{*} \\
(1.71) \\
\end{array}$ & $\begin{array}{l}10.53^{* *} \\
(2.27)\end{array}$ & $\begin{array}{c}-4.15 \\
(-0.77) \\
\end{array}$ & $\begin{array}{c}2.51 \\
(0.48) \\
\end{array}$ \\
\hline Period & \multicolumn{7}{|c|}{$\begin{array}{l}\left.\text { Estimated cumulative abnormal returns est(car } r_{i}\right) \\
\text { (z-statistics) }\end{array}$} \\
\hline $\begin{array}{l}\text { September } 23- \\
\text { September } 24\end{array}$ & $\begin{array}{c}4.97 \\
(0.66)\end{array}$ & $\begin{array}{c}1.09 \\
(0.17) \\
\end{array}$ & $\begin{array}{c}-1.93 \\
(-0.35)\end{array}$ & $\begin{array}{c}4.98 \\
(0.86)\end{array}$ & $\begin{array}{c}1.09 \\
(0.17)\end{array}$ & $\begin{array}{l}14.90^{*} \\
(1.95)\end{array}$ & $\begin{array}{c}7.73 \\
(1.04)\end{array}$ \\
\hline $\begin{array}{l}\text { September } 23- \\
\text { September } 27\end{array}$ & $\begin{array}{c}-13.29 \\
(-1.11)\end{array}$ & $\begin{array}{c}-11.80 \\
(-1.15)\end{array}$ & $\begin{array}{c}-5.53 \\
(-0.63)\end{array}$ & $\begin{array}{c}6.43 \\
(0.70)\end{array}$ & $\begin{array}{c}7.04 \\
(0.68)\end{array}$ & $\begin{array}{l}13.10 \\
(1.08)\end{array}$ & $\begin{array}{l}13.96 \\
(1.19)\end{array}$ \\
\hline $\begin{array}{l}\text { September } 23- \\
\text { October } 11\end{array}$ & $\begin{array}{c}-33.89 \\
(-1.63)\end{array}$ & $\begin{array}{l}-7.75 \\
(-0.43)\end{array}$ & $\begin{array}{c}-10.19 \\
(-0.66)\end{array}$ & $\begin{array}{l}18.53 \\
(0.17)\end{array}$ & $\begin{array}{c}1.41 \\
(0.08)\end{array}$ & $\begin{array}{c}-10.53 \\
(-0.50) \\
\end{array}$ & $\begin{array}{c}-4.80 \\
(-0.24) \\
\end{array}$ \\
\hline $\begin{array}{l}\text { October } 01- \\
\text { October } 31\end{array}$ & $\begin{array}{l}26.39 \\
(1.05)\end{array}$ & $\begin{array}{c}9.17 \\
(0.43)\end{array}$ & $\begin{array}{l}1.52 \\
(0.08)\end{array}$ & $\begin{array}{c}8.89 \\
(0.46)\end{array}$ & $\begin{array}{c}22.72 \\
(1.04)\end{array}$ & $\begin{array}{l}-0.89 \\
(-0.03)\end{array}$ & $\begin{array}{c}-26.98 \\
(-1.10)\end{array}$ \\
\hline $\begin{array}{l}\text { October } 01 \text { - } \\
\text { December } 30\end{array}$ & $\begin{array}{l}-49.95 \\
(-1.19) \\
\end{array}$ & $\begin{array}{c}-12.88 \\
(-0.36) \\
\end{array}$ & $\begin{array}{c}-26.94 \\
(-0.87)\end{array}$ & $\begin{array}{c}-17.59 \\
(-0.54)\end{array}$ & $\begin{array}{l}19.27 \\
(0.53) \\
\end{array}$ & $\begin{array}{c}-15.35 \\
(-0.36)\end{array}$ & $\begin{array}{c}-15.91 \\
(-0.39) \\
\end{array}$ \\
\hline
\end{tabular}

Note: * $(* *, * *)$ means that the null hypothesis that the abnormal returns $\mathrm{a} r_{\mathrm{i}}$ or the cumulative abnormal returns car $r_{i}$ are zero can be rejected at the $10 \%(5 \%, 1 \%)$ level of significance (according to the corresponding twotailed z-test). 
Table 8: Estimated abnormal returns est $\left(\mathrm{a} r_{i}\right)$ and estimated cumulative abnormal returns est $\left(\mathrm{car}_{i}\right)$ for each of the seven corporations exclusively engaged in renewable energies, basis: daily data and three-factor model

\begin{tabular}{|c|c|c|c|c|c|c|c|}
\hline & EECH & $\begin{array}{l}\text { ENERGIE- } \\
\text { KONTOR }\end{array}$ & NORDEX & $\begin{array}{l}\text { SOLAR- } \\
\text { PARC }\end{array}$ & $\begin{array}{l}\text { SOLAR- } \\
\text { WORLD }\end{array}$ & $\begin{array}{l}\text { SUN- } \\
\text { WAYS }\end{array}$ & $\begin{array}{l}\text { UMWELT- } \\
\text { KONTOR }\end{array}$ \\
\hline Day & \multicolumn{7}{|c|}{$\begin{array}{l}\text { Estimated abnormal returns est }\left(\mathrm{a} r_{i}\right) \\
\text { (z-statistics) }\end{array}$} \\
\hline September 23 & $\begin{array}{c}-4.40 \\
(-0.82)\end{array}$ & $\begin{array}{c}8.73^{*} \\
(1.91)\end{array}$ & $\begin{array}{c}4.11 \\
(1.05)\end{array}$ & $\begin{array}{c}1.00 \\
(0.24)\end{array}$ & $\begin{array}{c}8.27^{*} \\
(1.79)\end{array}$ & $\begin{array}{l}14.09^{* * * *} \\
(2.62)\end{array}$ & $\begin{array}{c}8.26 \\
(1.58)\end{array}$ \\
\hline September 24 & $\begin{array}{r}9.76^{*} \\
(1.83) \\
\end{array}$ & $\begin{array}{c}-6.66 \\
(-1.46)\end{array}$ & $\begin{array}{c}-4.31 \\
(-1.10)\end{array}$ & $\begin{array}{c}4.39 \\
(1.07)\end{array}$ & $\begin{array}{c}-5.41 \\
(-1.17)\end{array}$ & $\begin{array}{c}2.65 \\
(0.49) \\
\end{array}$ & $\begin{array}{l}-1.44 \\
(-0.27)\end{array}$ \\
\hline September 25 & $\begin{array}{l}-11.16^{* *} \\
(-2.09)\end{array}$ & $\begin{array}{c}3.80 \\
(0.83) \\
\end{array}$ & $\begin{array}{c}-4.92 \\
(-1.26) \\
\end{array}$ & $\begin{array}{c}0.24 \\
(0.06)\end{array}$ & $\begin{array}{c}-3.84 \\
(-0.83) \\
\end{array}$ & $\begin{array}{c}-3.10 \\
(-0.58) \\
\end{array}$ & $\begin{array}{c}2.30 \\
(0.44) \\
\end{array}$ \\
\hline September 26 & $\begin{array}{c}3.49 \\
(0.65)\end{array}$ & $\begin{array}{c}-7.49 \\
(-1.64)\end{array}$ & $\begin{array}{c}1.08 \\
(0.28)\end{array}$ & $\begin{array}{c}0.74 \\
(0.18)\end{array}$ & $\begin{array}{c}0.62 \\
(0.13)\end{array}$ & $\begin{array}{c}-0.41 \\
(-0.08)\end{array}$ & $\begin{array}{c}-3.36 \\
(-0.64)\end{array}$ \\
\hline September 27 & $\begin{array}{l}-9.32^{*} \\
(-1.75)\end{array}$ & $\begin{array}{l}-9.07^{* *} \\
(-1.99) \\
\end{array}$ & $\begin{array}{c}0.95 \\
(0.24) \\
\end{array}$ & $\begin{array}{c}0.81 \\
(0.20)\end{array}$ & $\begin{array}{l}9.09^{* *} \\
(1.97)\end{array}$ & $\begin{array}{c}2.73 \\
(0.51) \\
\end{array}$ & $\begin{array}{c}6.41 \\
(1.22) \\
\end{array}$ \\
\hline September 30 & $\begin{array}{c}-2.87 \\
(-0.54)\end{array}$ & $\begin{array}{c}7.50 \\
(1.64)\end{array}$ & $\begin{array}{c}-0.37 \\
(-0.10)\end{array}$ & $\begin{array}{c}0.63 \\
(0.15)\end{array}$ & $\begin{array}{c}-10.11^{* *} \\
(-2.19)\end{array}$ & $\begin{array}{c}-9.47^{*} \\
(-1.76)\end{array}$ & $\begin{array}{c}3.31 \\
(0.63)\end{array}$ \\
\hline October 01 & $\begin{array}{l}-33.82^{*+*+*} \\
(-6.34)\end{array}$ & $\begin{array}{l}-3.48 \\
(-0.76)\end{array}$ & $\begin{array}{l}-11.49^{* * *} \\
(-2.94)\end{array}$ & $\begin{array}{c}0.52 \\
(0.13)\end{array}$ & $\begin{array}{l}-2.13 \\
(-0.46)\end{array}$ & $\begin{array}{l}-1.83 \\
(-0.34)\end{array}$ & $\begin{array}{l}-13.16^{* *} \\
(-2.51)\end{array}$ \\
\hline October 02 & $\begin{array}{l}-17.24^{* * * *} \\
(-3.23)\end{array}$ & $\begin{array}{c}-0.32 \\
(-0.07) \\
\end{array}$ & $\begin{array}{c}4.18 \\
(1.07) \\
\end{array}$ & $\begin{array}{c}0.75 \\
(0.18) \\
\end{array}$ & $\begin{array}{c}-1.33 \\
(-0.29) \\
\end{array}$ & $\begin{array}{c}-7.71 \\
(-1.43) \\
\end{array}$ & $\begin{array}{c}-6.42 \\
(-1.23) \\
\end{array}$ \\
\hline October 03 & $\begin{array}{c}3.10 \\
(0.58) \\
\end{array}$ & $\begin{array}{c}8.45^{*} \\
(1.85) \\
\end{array}$ & $\begin{array}{c}-0.29 \\
(-0.07)\end{array}$ & $\begin{array}{c}2.50 \\
(0.61)\end{array}$ & $\begin{array}{c}1.13 \\
(0.25) \\
\end{array}$ & $\begin{array}{c}2.97 \\
(0.55) \\
\end{array}$ & $\begin{array}{c}5.96 \\
(1.14)\end{array}$ \\
\hline October 04 & $\begin{array}{l}31.33^{* * * *} \\
(5.87)\end{array}$ & $\begin{array}{c}-1.63 \\
(-0.36)\end{array}$ & $\begin{array}{c}1.69 \\
(0.43) \\
\end{array}$ & $\begin{array}{c}0.64 \\
(0.16)\end{array}$ & $\begin{array}{c}4.99 \\
(1.08)\end{array}$ & $\begin{array}{c}-8.38 \\
(-1.56)\end{array}$ & $\begin{array}{c}1.47 \\
(0.28)\end{array}$ \\
\hline October 07 & $\begin{array}{c}7.21 \\
(1.35)\end{array}$ & $\begin{array}{c}7.51^{*} \\
(1.65)\end{array}$ & $\begin{array}{c}3.30 \\
(0.84)\end{array}$ & $\begin{array}{c}-0.77 \\
(-0.19)\end{array}$ & $\begin{array}{c}-6.43 \\
(-1.39)\end{array}$ & $\begin{array}{c}5.42 \\
(1.01)\end{array}$ & $\begin{array}{c}-0.71 \\
(-0.14)\end{array}$ \\
\hline October 08 & $\begin{array}{c}-4.81 \\
(-0.90)\end{array}$ & $\begin{array}{c}-0.80 \\
(-0.17)\end{array}$ & $\begin{array}{c}1.69 \\
(0.43)\end{array}$ & $\begin{array}{c}0.42 \\
(0.10)\end{array}$ & $\begin{array}{c}7.77^{*} \\
(1.68) \\
\end{array}$ & $\begin{array}{c}-5.17 \\
(-0.96)\end{array}$ & $\begin{array}{c}-9.27^{*} \\
(-1.77) \\
\end{array}$ \\
\hline October 09 & $\begin{array}{c}-14.26^{* *+*} \\
(-2.67)\end{array}$ & $\begin{array}{c}-2.71 \\
(-0.59)\end{array}$ & $\begin{array}{c}4.61 \\
(1.18)\end{array}$ & $\begin{array}{c}0.76 \\
(0.19)\end{array}$ & $\begin{array}{c}-1.36 \\
(-0.29)\end{array}$ & $\begin{array}{c}1.53 \\
(0.28)\end{array}$ & $\begin{array}{c}-4.91 \\
(-0.94)\end{array}$ \\
\hline October 10 & $\begin{array}{c}7.92 \\
(1.48)\end{array}$ & $\begin{array}{c}-4.18 \\
(-0.91)\end{array}$ & $\begin{array}{c}-10.95^{*+*} \\
(-2.80)\end{array}$ & $\begin{array}{c}0.54 \\
(0.13)\end{array}$ & $\begin{array}{c}-6.19 \\
(-1.34)\end{array}$ & $\begin{array}{c}6.76 \\
(1.26)\end{array}$ & $\begin{array}{c}0.30 \\
(0.06)\end{array}$ \\
\hline October 11 & $\begin{array}{c}4.69 \\
(0.88) \\
\end{array}$ & $\begin{array}{c}-4.68 \\
(-1.03) \\
\end{array}$ & $\begin{array}{c}6.09 \\
(1.56) \\
\end{array}$ & $\begin{array}{c}7.01^{*} \\
(1.71)\end{array}$ & $\begin{array}{l}10.24^{* *} \\
(2.22) \\
\end{array}$ & $\begin{array}{c}-4.33 \\
(-0.81) \\
\end{array}$ & $\begin{array}{c}2.55 \\
(0.49) \\
\end{array}$ \\
\hline Period & \multicolumn{7}{|c|}{$\begin{array}{l}\left.\text { Estimated cumulative abnormal returns est(car } r_{i}\right) \\
\text { (z-statistics) }\end{array}$} \\
\hline $\begin{array}{l}\text { September } 23- \\
\text { September } 24\end{array}$ & $\begin{array}{c}5.36 \\
(0.71) \\
\end{array}$ & $\begin{array}{l}2.07 \\
(0.32)\end{array}$ & $\begin{array}{c}-0.20 \\
(-0.04)\end{array}$ & $\begin{array}{c}5.39 \\
(0.93)\end{array}$ & $\begin{array}{c}2.86 \\
(0.44)\end{array}$ & $\begin{array}{l}16.74^{* *} \\
(2.20)\end{array}$ & $\begin{array}{c}6.82 \\
(0.92)\end{array}$ \\
\hline $\begin{array}{l}\text { September } 23- \\
\text { September } 27\end{array}$ & $\begin{array}{c}-11.63 \\
(-0.97)\end{array}$ & $\begin{array}{c}-10.69 \\
(-1.05)\end{array}$ & $\begin{array}{l}-3.09 \\
(-0.35)\end{array}$ & $\begin{array}{c}7.18 \\
(0.78)\end{array}$ & $\begin{array}{c}8.73 \\
(0.85)\end{array}$ & $\begin{array}{l}15.96 \\
(1.33)\end{array}$ & $\begin{array}{l}12.17 \\
(1.04)\end{array}$ \\
\hline $\begin{array}{l}\text { September } 23- \\
\text { October } 11\end{array}$ & $\begin{array}{l}-30.35 \\
(-1.47) \\
\end{array}$ & $\begin{array}{l}-5.04 \\
(-0.29)\end{array}$ & $\begin{array}{c}-4.65 \\
(-0.31) \\
\end{array}$ & $\begin{array}{l}20.19 \\
(1.27)\end{array}$ & $\begin{array}{c}5.32 \\
(0.30) \\
\end{array}$ & $\begin{array}{c}-4.24 \\
(-0.20) \\
\end{array}$ & $\begin{array}{c}-8.71 \\
(-0.43) \\
\end{array}$ \\
\hline $\begin{array}{l}\text { October } 01- \\
\text { October } 31\end{array}$ & $\begin{array}{l}28.25 \\
(1.13)\end{array}$ & $\begin{array}{c}9.76 \\
(0.46)\end{array}$ & $\begin{array}{c}3.10 \\
(0.17)\end{array}$ & $\begin{array}{c}9.49 \\
(0.49)\end{array}$ & $\begin{array}{l}23.37 \\
(1.08)\end{array}$ & $\begin{array}{l}1.03 \\
(0.04)\end{array}$ & $\begin{array}{c}-28.54 \\
(-1.16)\end{array}$ \\
\hline $\begin{array}{l}\text { October } 01 \text { - } \\
\text { December } 30\end{array}$ & $\begin{array}{l}-49.82 \\
(-1.19) \\
\end{array}$ & $\begin{array}{c}-13.69 \\
(-0.38) \\
\end{array}$ & $\begin{array}{c}-28.96 \\
(-0.94)\end{array}$ & $\begin{array}{l}-18.16 \\
(-0.56)\end{array}$ & $\begin{array}{l}17.70 \\
(0.49)\end{array}$ & $\begin{array}{c}-17.40 \\
(-0.41)\end{array}$ & $\begin{array}{c}-15.45 \\
(-0.37) \\
\end{array}$ \\
\hline
\end{tabular}

Note: * $(* *, * *)$ means that the null hypothesis that the abnormal returns $\mathrm{a} r_{\mathrm{i}}$ or the cumulative abnormal returns car $r_{i}$ are zero can be rejected at the $10 \%(5 \%, 1 \%)$ level of significance (according to the corresponding twotailed z-test). 